

\title{
Explorations for Water Supplies on the Public Domain, 1960
}

\author{
By Wm. S. Eisenlohr, Jr., and others
}

Prepared as part of the Soil and Moisture Conservation Program of the Department of the Interior

Geological, Survey Circular 461 
United States Department of the Interior STEWART L. UDALL, SECRETARY

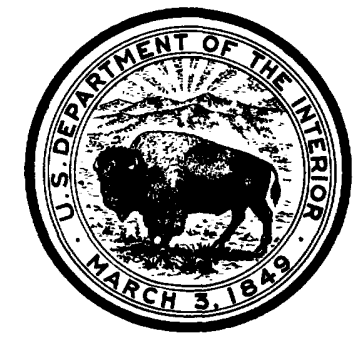

Geological Survey

THOMAS B. NOLAN, Dirbctor

x

Free on application to the U.S. Geological Survey, Washington 25, D. C. 


\section{COITTENTS}

Page

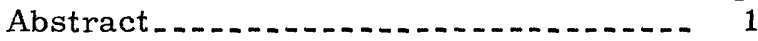

Introduction........................... 1

Soil and moisture conservation program,

by K. R. Melin _..... 1

Arizona, by C. T. Sumsion.......... 2

Bureau of Land Management Grazing

District 1.................. 2

Bureau of Land Management Grazing

District 2 ...................... 2

Bureau of Land Management Grazing District 3....... 3

California, by C. T. Snyder ........ 5

Bureau of Land Management Bakers field Grazing District ............ 5

Colorado, by M. C. Van Lewen ........ 6

Bureau of Land Management Grazing District 8..................... 6

Montana .......................... 7

Bureau of Land Management Grazing District 2, by M. C. Van Lewen .... 7

Bureau of Land Management Grazing District 3, by M. C. Van Lewen ..._ 8

Bureau of Land Management Grazing District 4, by N. J. King......... 8
Nevada, by C. T. Snyder

Bureau of Land Management Elko Grazing District............ 13

Bureau of Land Management Pyramid Grazing District ........ 14

Oregon, by C. T. Snyder......... 16

Bureau of Land Management Vale Grazing District............... 16

Bureau of Land Management Prine ville Grazing District _......... 18

Utah, by Charles E. Sloan _........ 18

Bureau of Land Management Grazing District 6................... 18

Bureau of Land Management Grazing District 9...... 19

Wyoming _....................... 21

Bureau of Land Management Grazing District 2, by M. C. Van Lewen...- 21

Bureau of Land Management Grazing Districts 4 and 5, by M. C. Van

Lewen.........................

Bureau of Land Management Grazing District 6 , by Charles E.

Sloan

\section{ILLUSTRATIONS}

Figure 1. Index map showing by dots or pattern the general location of areas described.

\section{TABLES}

Table 1. Well and spring locations examined or drilled in Arizona, 1960

2. Well and spring locations examined or drilled in California, $1960 \ldots$

3. Well and spring locations examined or drilled in Colorado, 1960

4. Well and spring locations examined or drilled in Montana, 1960

5. Well and spring locations examined or drilled in Nevada, 1960

6. Well and spring locations examined or drilled in Oregon, 1960

7. Well and spring locations examined or drilled in Utah, 1960

8. Well and spring locations examined or drilled in Wyoming, $1960 \ldots$ 


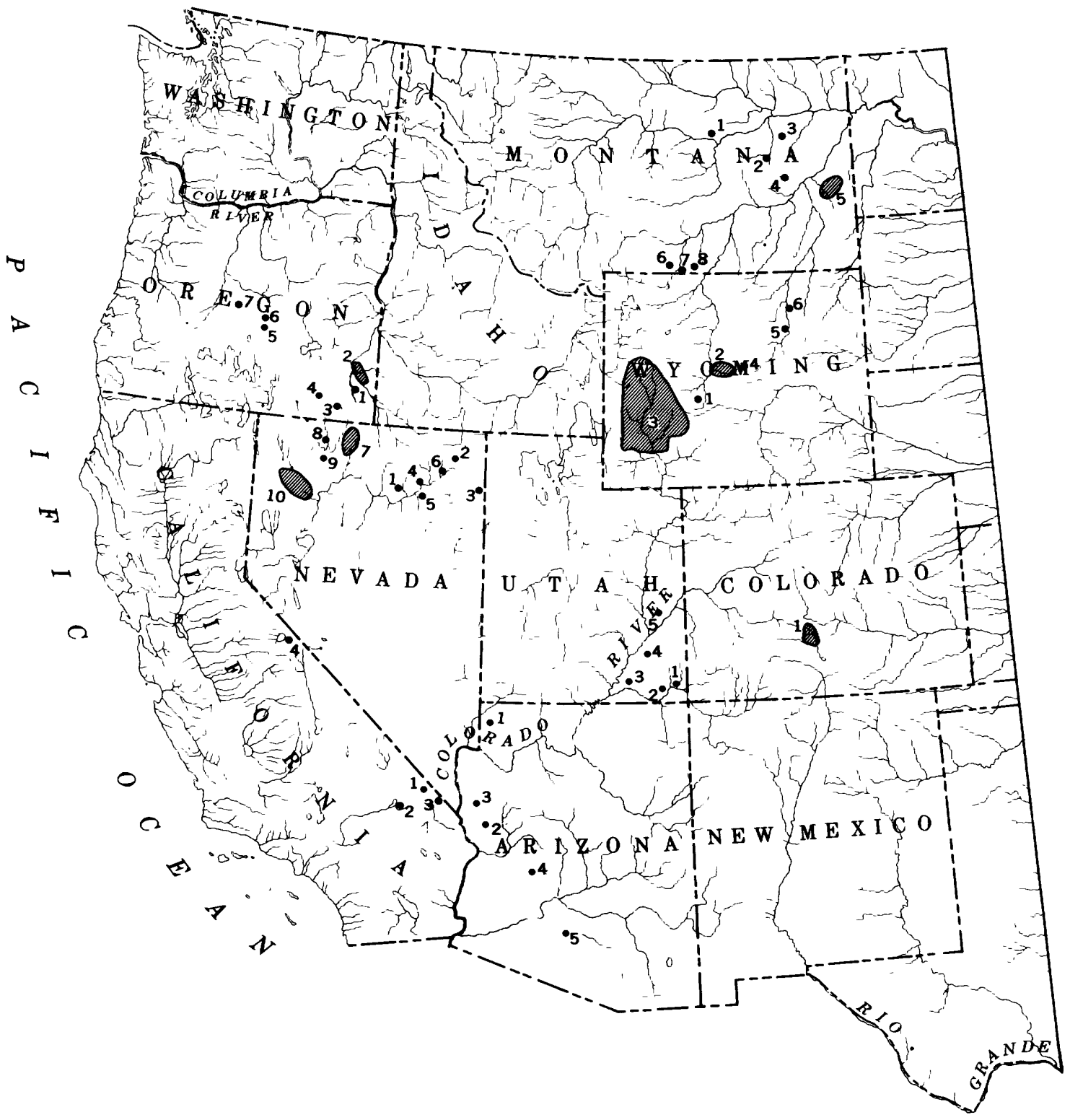

Figure 1. - Index map showing by dots or pattern the general location of areas described. Numbers identifying areas are those shown in table for appropriate State. 


\title{
Explorations for Water Supplies on the Public Domain, 1960
}

\author{
By Wm. S. Eisenlohr, Jr., and others
}

\begin{abstract}
In making reconnaissances for water supplies on the public domain as part of the Soil and Moisture Conservation Program of the Department of the Interior, the Geological Survey obtains information on the availability of water that is useful for other purposes or in other areas. This report contains the information thus collected during the calendar year 1960 in 46 areas scattered throughout 8 Western States. The accompanying tables list the sites of wells investigated, existing wells, springs, and wells drilled in 1960 as a result of investigations in that or previous years.
\end{abstract}

\section{INTRODUCTION}

This report summarizes the explorations for water, for use by stock grazing on the public domain, that were made in eight Western States (fig. 1) in 1960 as part of the Soil and Moisture Conservation Program of the Department of the Interior. Explorations made in previous years as part of this program are being summarized by areas for publication as water-supply papers.

The investigations on which this report is based were made for other bureaus of the Department of the Interior. They were concerned with finding water within a specified area and resulted in detailed recommendations on how to develop the needed water supply. The recommendations made are beyond the scope of this report, but some information of general interest on the availability of water was usually obtained in each investigation. The purpose of this report is to present the useful information obtained during the calendar year 1960 .

The reconnaissances for water supplies rarely covered more than a few days in any area. Thus the geologic information given is usually very general and should be used with caution when inferring conditions at any dis tance from the site being described. The places where water has already been found is important information when looking for new sources of water. For this reason, known sources of water, such as wells and springs, are listed for the areas investigated. Almost equally important are known failures to find water, if adequate information about the venture is available. In the tables of well and spring locations for each State, arranged by grazing district, are given in order: the sites investigated, existing wells, known springs, and finally wells drilled in 1960 as part of the Soil and Moisture Conservation Program. This information is presented as a guide to others faced with the problem of obtaining water supplies in these parts of the arid West.

The report was prepared by Wm.S. Eisen lohr, Jr., who supervised the writing of the contributions by the authors named.

\section{SOIL AND MOISTURE CONSERVATION PROGRAM}

$$
\text { By K. R. MELIN }
$$

Under the Soil and Moisture Conservation Program of the Department of the Interior, the Geological Survey conducts investigations and research to provide basic information needed in all facets of conservation of lands administered by the Department. The conservation program, in abroad sense, includes the protection of the land to achieve optimum production of forage as well as to retard downstream damage resulting from floods, such as channel cutting or deposition of sediment eroded from upland areas.

For the most part, the lands considered in this report are arid or semiarid, and the vegetation they bear is generally sparse. Nevertheless, despite their relatively low unit forage production, the lands traditionally 
have been used for grazing, and because of the great extent of lands involved, this use has formed and continues to form an impor tant part of the economy of several Western States.

Owing to the sparse cover of vegetation as well as to the inherent erodibility of the soils in many areas, grazing must be managed carefully to prevent permanent deterioration of the forage, as well as to prevent erosion, which will occur when concentrations of livestock are such that vegetation is depleted, soil is compacted, and stock-trails become intrenched. A very important aid to manage ment is proper spacing of water supplies. The required spacing differs from one area to another depending upon distribution of for age and character of terrain. Economic factors, such as the cost of water development in relation to the forage crop, must also be considered by the land-administration agencies.

In many localities water supplies about 2 miles apart are desirable, but in others wider spacing generally will suffice. On the other hand, in areas where forage production is in creased by mechanical treatments of the land, even closer spacing of water supplies may be advantageous. Generally, however, these objectives in range-water development have been achieved on only a relatively small part of the lands of the Department of the Interior. Consequently, the program of stockwater development is expected to continue together with installation of other conservation practices. To furnish basic information necessary for such development, additional investigations will be made and reports prepared by the Geological Survey.

\section{ARIZONA}

By C.T. SUMSION

\section{BUREAU OF LAND MANAGEMENT GRAZING DISTRICT 1}

The Bureau of Land Management Grazing District 1 comprises parts of Mohave and Coconino Counties. Explorations for water in 1960 were made in the Virgin Mountains area (1, fig. 1) where three well sites were selected. Recommendations for stock-water sources were based on field examinations by the author.
Well sites 1-3 (table 1) were examined in the area east and southeast of the Virgin Mountains in October.

Site 1 is adjacent to Tom and Cull Wash, an ephemeral stream that flows in a channel underlain to considerable depth by unconsoli dated alluvium. Runoff from the drainage basin upstream from the site should provide adequate recharge to maintain perennial underflow in the alluvium of the wash. The estimated depth to water is based on the inferred thickness of alluvium at the site.

Site 2 is near Cedar Wash in the outcrop area of the Shinarump Member of the Chinle Formation of Late Triassic age. In this area the Shinarump Member is largely sandstone with some lenses of conglomerate. Records of test holes drilled previously in this immediate area show that water can be found in these rocks at a depth of about 40 feet.

The terrain at site 3 is similar to that at Jacobs Well (E1, table 1 ), which is about 9 miles north of site 3 , and obtains water from unconsolidated sediments deposited in Grand Wash trough at the southeast end of the Virgin Mountains: A second well (E2, table 1) about 4 miles southeast of the site also obtains water from the alluvial fill in Grand Wash trough. The estimated depth to water at site 3 is based on the depth to water at these wells with appropriate compensations for differences in elevation and probable differences in the configuration of the bedrock floor of Grand Wash trough.

Water in this area is reported to be of good quality for both stock and domestic use.

\section{BUREAU OF LAND MANAGEMENT GRAZING DISTRICT 2}

Bureau of Land Management Grazing Dis trict 2 comprises parts of Mohave and Yavapai Counties. Explorations for water in 1960 were made in 2 areas where 10 well sites were located. Recommendations for stockwater sources were based on field examina tions by the author.

Yucca area

An area east of Yucca (2, fig. 1) on the west slopes of the Hualpai and McCracken 
Mountains was examined in January to determine the prospects of developing stock-water supplies at nine well sites selected by the Bureau of Land Management. Both mountain ranges are composed largely of granite and granitic gneiss of low permeability. Small springs or seeps issue locally where the bedrock is sufficiently fractured to intercept surface flows, but predictable occurrences of ground water are limited mainly to local underflow in the coarse, unconsolidated alluvial deposits that underlie the larger washes. Several comparatively shallow wells have been dug or drilled into these channel deposits to tap the ground water, but commonly these wells are seasonal rather than perennial sources of water.

All but one of the proposed sites (5-12, table 1) are in washes where wells or springs, either upstream or downstream from the sites, attest to the occurrence of underflow in the channel alluvium. The other site $(4$, table 1) is underlain by impermeable granitic bedrock, and therefore, drilling was not recommended.

Water in this area is reported to be of suit able quality for both stock and domestic use.

\section{Kingman area}

In June, well site 13 (table 1) near the Bureau of Land Management's warehouse compound about 2 miles southwest of Kingman (3, fig. 1) was examined to determine if water could be obtained that would be suitable for both warehouse and livestock use.

An outcrop of granitic rock immediately south of the compound indicates impermeable bedrock at shallow depth beneath the warehouse area. About a half mile north and northwest of the compound, volcanic rocks of both rhyolitic and basaltic composition crop out to form steep cliffs. The area between these cliffs and the outcrop of granitic rock is covered by alluvium and volcanic debris of undetermined thickness below which may lie either granitic or volcanic rocks. As wells in the vicinity of Kingman (E9-E11, table 1) prove that water suitable in quality for the intended use can be obtained from the volcanic rocks, the most promising location for a well appears to be in the proximity of the outcrop of volcanic rocks.
BUREAU OF LAND MANAGEMENT GRAZING IS TRICT 3

The Bureau of Land Management Grazing District 3 comprises parts of Maricopa, Yuma, Pima, Pinal, and Yavapai Counties. Explorations for water in 1960 were made in two a reas where three well sites were located. Recommendations for stock-water sources were based on field examinations by the author.

\section{Wickenburg area}

Well sites 14-15 (table 1) were examined in the vicinity of Wickenburg (4, fig. 1) in September.

The geologic and topographic settings of the two sites, No. 14 in the Vulture Mountains a bout 10 miles southwest of Wickenburg, and No. 15 immediately west of a basalt hill known locally as Funeral Mountain about 10 miles south of Wickenburg, are similar. Both sites are underlain by alluvium in unnamed washes whose drainage areas are considered to be large enough to supply underflow beneath the sites throughout the greater part of the year. The estimated depths to water of suitable quality are based on the inferred thickness of alluvium at the sites.

\section{Table Top Mountain area}

A broad alluvial fan deposit that extends southwestward from Table Top Mountain into Vekol Valley (5, fig. 1) was examined in September to determine the occurrence of ground water. Three basalt hills protrude from the deposit near the head of the fan. The alinement of these bedrock outcrops in a northwest direction suggests local faulting as the probable cause of the present bedrock relief. If a well is drilled southwest of the basalt hills over what is inferred to be the downdropped block, the well should not reach bedrock above the level of the local water table as indicated by the static water level in a well (E12, table 1) near Vekol Wash. Consequently, there can be little doubt of finding water in this part of the fan. If, however, a well is drilled northeast of the basalt hills near the head of the fan, it may reach bedrock at shallow depth. Water may be found at the contact of the alluvium and bedrock or in the volcanic rocks that are believed to underlie this part of the fan, but there is some risk of obtaining a dry hole. 
Table 1.-Well and spring locations examined or drilled in Arizona, 1960

[Site number without prefix indicates site only and depth of well and depth to water are estimates and aquifer is inferred; $\mathrm{E}$ with site number indicates existing well at time of examination. Names of aquifers are shown by standard symbols for formations: Rcs, Shinarump Member of Chinle Formation; Tv, volcanic rocks; Tb, basalt; Qal, alluvium]

\begin{tabular}{|c|c|c|c|c|c|c|c|c|c|c|c|c|}
\hline \multirow{3}{*}{$\begin{array}{l}\text { Site } \\
\text { No. }\end{array}$} & \multicolumn{5}{|c|}{ Location } & \multirow{3}{*}{ Name } & \multirow{3}{*}{$\begin{array}{l}\text { Eleva - } \\
\text { tion of } \\
\text { land } \\
\text { surface } \\
\text { (feet) }\end{array}$} & \multirow{3}{*}{$\begin{array}{l}\text { Depth } \\
\text { of } \\
\text { well } \\
\text { (feet) }\end{array}$} & \multirow{3}{*}{$\begin{array}{c}\text { Depth } \\
\text { of } \\
\text { water } \\
\text { (feet) }\end{array}$} & \multirow{3}{*}{ Aquifer } & \multirow{3}{*}{$\begin{array}{l}\text { Yield } \\
\text { (gpm) }\end{array}$} & \multirow{3}{*}{ Remarks } \\
\hline & \multirow{2}{*}{$\begin{array}{c}\text { Area on } \\
\text { fig. } 1\end{array}$} & \multicolumn{2}{|c|}{ Section } & \multirow{2}{*}{$T$. } & \multirow{2}{*}{ R. } & & & & & & & \\
\hline & & Quarter & $\mathrm{Na}$ & & & & & & & & & \\
\hline
\end{tabular}

Bureau of Land Management Grazing District 1

\begin{tabular}{|c|c|c|c|c|c|c|c|c|c|c|}
\hline 1 & 1 & $\mathrm{NE}$ & 7 & $37 \mathrm{~N} .15 \mathrm{~W}$. & $-\ldots-\ldots$ & 3,680 & $100-200$ & $\ldots \ldots$ & Qal & \\
\hline 2 & 1 & SW & 27 & $37 \mathrm{~N} .16 \mathrm{~W}$. & & 3,800 & $40-50$ & $\ldots$ & Res & \\
\hline 3 & 1 & Sw & 9 & $36 \mathrm{~N}, 15 \mathrm{~W}$. & $\ldots$ & 3,010 & $500-700$ & $\ldots$ & Qal & \\
\hline $\mathrm{E} 1$ & 1 & SW & 27 & $38 \mathrm{~N} .15 \mathrm{~W}$. & Jacobs Well & 4,155 & 806 & 780 & Qal & \\
\hline $\mathrm{E} 2$ & 1 & NW & 36 & $36 \mathrm{~N} .15 \mathrm{~W}$. & $\ldots \ldots$ & 2,700 & 548 & 518 & Qal & \\
\hline
\end{tabular}

Bureau of Land Management Grazing District 2

\begin{tabular}{|c|c|c|c|c|c|c|c|c|c|c|c|}
\hline 4 & 2 & $\mathrm{NW}$ & 6 & $18 \mathrm{~N} .16 \mathrm{~W}$ & - & 3,850 & & & $-\cdots$ & & $\begin{array}{l}\text { Drilling not } \\
\text { recom- } \\
\text { mended. }\end{array}$ \\
\hline 5 & 2 & NW & 5 & $18 \mathrm{~N} .16 \mathrm{~W}$. & - - - - - & 4,300 & $100-150$ & & Qal & & \\
\hline 6 & 2 & NWSW & 5 & $18 \mathrm{~N} .16 \mathrm{~W}$. & $\ldots-\ldots$ & 4,100 & $100-150$ & & Qal & --- & \\
\hline 7 & 2 & NW & 8 & $18 \mathrm{~N} .16 \mathrm{~W}$. & 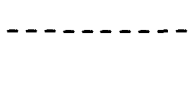 & 4,000 & $40-50$ & - & Qal & & $\begin{array}{l}\text { Previously } \\
\text { drilled to } 25 \\
\text { ft. depth. }\end{array}$ \\
\hline 8 & 2 & $\mathrm{NE}$ & 24 & $17 \mathrm{~N} .16 \mathrm{~W}$ & $\ldots$ & 3,800 & $100-150$ & & Qal &.- & \\
\hline 9 & 2 & NW & 30 & $17 \mathrm{~N} .15 \mathrm{~W}$. & $\ldots$ & 3,950 & $100-150$ & & Qal & & \\
\hline 10 & 2 & W center & 18 & $16 \mathrm{~N} .15 \mathrm{~W}$. & -.-.-.-. & 4,350 & $150-200$ & & Qal & & \\
\hline 11 & 2 & sw & 32 & $16 \mathrm{~N} .15 \mathrm{~W}$. & $\ldots \ldots$ & 4,100 & $100-150$ & & Qal & & \\
\hline 12 & 2 & center & 30 & $13 \mathrm{~N}, 15 \mathrm{~W}$ & $\ldots$ & 1,950 & $100-200$ & & Qal & & \\
\hline 13 & 3 & NW & 34 & $21 \mathrm{~N} .17 \mathrm{~W}$ & $\ldots-\ldots$ & 3,000 & $100-125$ & & $\begin{array}{l}\text { Qal or } \\
\text { TV }\end{array}$ & & \\
\hline $\mathrm{E} 3$ & 2 & NW & 33 & $19 \mathrm{~N} .16 \mathrm{~W}$. & & 5,500 & 70 & & Qal & & \\
\hline $\mathrm{E} 4$ & 2 & NW & 19 & $17 \mathrm{~N} .15 \mathrm{~W}$. & - & 3,900 & 189 & 139 & Qal & $\ldots$ & \\
\hline E5 & 2 & NW & 26 & $17 \mathrm{~N} .16 \mathrm{~W}$ & - & 3,500 & 256 & 60 & Qal & $\ldots$ & \\
\hline E6 & 2 & SW & 14 & $16 \mathrm{~N} .16 \mathrm{~W}$. & . & 3,950 & 190 & 50 & Qal & & \\
\hline E7 & 2 & NW & 33 & $16 \mathrm{~N} .15 \mathrm{~W}$. & $-\ldots-\ldots$ & 4,600 & 28 & & Qal & & \\
\hline $\mathrm{E} 8$ & 2 & $\mathrm{SE}$ & 26 & $13 \mathrm{~N} .16 \mathrm{~W}$ & $\ldots-\ldots$ & 1,950 & 100 & & Qal & & \\
\hline E9 & 3 & NWSE & 34 & $21 \mathrm{~N} .17 \mathrm{~W}$ & - & 2,950 & 60 & & $\mathrm{~Tb}$ & & \\
\hline E10 & 3 & NW & 35 & $21 \mathrm{~N} .17 \mathrm{~W}$ & 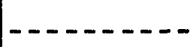 & 2,990 & 106 & & $\mathrm{Tv}$ & & \\
\hline E1 1 & 3 & $\mathrm{SE}$ & 34 & $21 \mathrm{~N} .17 \mathrm{~W}$ & $\ldots-\ldots$ & 2,950 & 80 & 64 & $\mathrm{TV}$ & & \\
\hline
\end{tabular}

Bureau of Land Management Grazing District 3

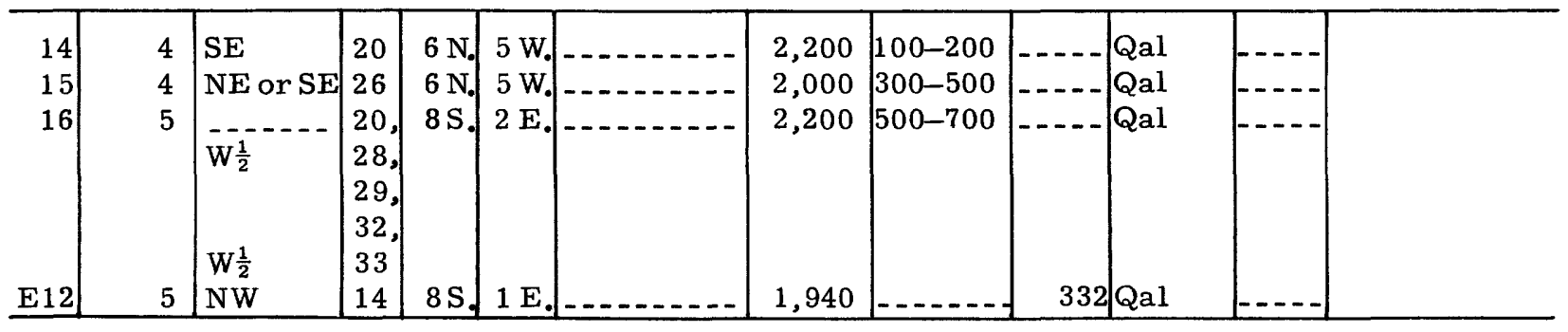


Owing to the favorable conditions of recharge at the upper part of the fan and the large size of the recharge area, prospects of finding water of suitable'quality for stock use are generally favorable anywhere on the fan deposit. Therefore, a specific well site was not selected.

\section{CALIFORNIA}

\author{
By C. T. SNYDER
}

\section{BUREAU OF LAND MANAGEMENT BAKERSFIELD GRAZING DISTRICT}

Bakersfield Grazing District extends from San Bernardino County on the south to Mono County on the north and includes intervening counties in southern and eastern California. Explorations for water in 1960 were made in four areas where one spring and three well sites were examined. Recommendations for the development of stock water in these areas were based on fieldwork by the author and a report by Gilbert (1941).

\section{Ivanpah Valley}

Ivanpah Valley (1, fig. 1) was visited in mid-February. Well site 1 (table 2) was selected for drilling on the alluvial fan at the head of an unnamed tributary to Ivanpah Val ley. This site, centrally located on the alluvial fan, was recommended for drilling to explore the alluvium for ground water that may be moving westward from the slopes of the New York Mountains toward Ivanpah Val ley. No wells have been drilled into this al luvial fan, but wells drilled into similar fans elsewhere are usually successful. Water has also been found in the valley fill of Ivanpah Valley.

\section{Old Dad Mountain area}

The investigation in Old Dad Mountain area was made to determine the feasibility of developing a potential spring (S1, table 2) along an unnamed dry wash east of Old Dad Mountain (2, fig. 1). This area is called Burro Holes because wild burros dig into the sand for water that is moving as underflow through the alluvium about 2 feet below the surface. One such hole, still containing water, was found during the examination. A well drilled into the alluvium of the stream channel also contained water, but a well drilled into the bedrock on the south bank of the wash was dry despite the fact that the wells are only a few yards apart. It was concluded that the underflow in the wash could be developed as a spring for stock water.

\section{Piute Valley}

In Piute Valley a site (2, table 2) was selected for exploratory drilling on the alluvial fan of an unnamed wash that flows eastward from the Piute Range to Piute Wash (3, fig. 1). The alluvial fan is fairly small and overlies eastward-dipping beds of basalt and bedded tuff of Tertiary age, but is in the area where water is needed near the foot of the mountains. The Piute Mountains west of the site are an uplifted fault block of eastward-dipping volcanic and pyroclastic rocks. Water may occur in the alluvial fan or in permeable parts of the underlying beds. No wells or springs are known to occur nearby, but the material in the alluvial fans and the underlying beds are potentially water bearing. As no other sources of water are available, exploratory drilling here seems to be justified.

\section{Mono Lake area}

The Mnno Lake area (4, fig. 1) was visited in June, and well site 3 (table 2) was selected near the head of an alluvium-filled basin in the Cowtrack Mountains about 8 miles southeast of Mono Lake. The geology of the area has been mapped by Gilbert (1941). The only place where it appears that a successful well could be drilled is in a basin that has been formed by erosion and faulting of the Tertiary and Quaternary volcanic rocks of the surrounding mountains. The rocks exposed there are dense and appear to be non water bearing so that the best chance for obtaining water would be the alluvium. No wells or springs have been reported in the area nearby. The alluvium appears to be sufficiently permeable to permit rapid infiltration of precipitation, as there are no signs of an alluvial fan nor of dry stream channels in the basin. There is a large risk, however, that no water can be obtained at this site.

\section{REFERENCE FOR CALIFORNIA}

Gilbert, C. M., 1941, Late Tertiary geology southeast of Mono Lake, California: Geol. Soc. America Bull. v. 52, no. 6, p. 781815. 
Table 2.-Well and spring locations examined or drilled in California, 1960

[Site number without prefix indicates site only and depth of well and depth to water are estimated and aquifer is inferred; $S$ with site number indicates spring. Names of aquifers are shown by standard symbols for formations: Qal, Quaternary alluvium; QTV, Quaternary and Tertiary volcanic rocks, undifferentiated; $\mathrm{Tv}$, Tertiary volcanic rocks, undifferentiated]

\begin{tabular}{|c|c|c|c|c|c|c|c|c|c|c|c|c|}
\hline \multirow{3}{*}{$\begin{array}{c}\text { Site } \\
\text { No. }\end{array}$} & \multicolumn{5}{|c|}{ Location } & \multirow{3}{*}{ Name } & \multirow{3}{*}{$\begin{array}{c}\text { Eleva- } \\
\text { tion of } \\
\text { land } \\
\text { surface } \\
\text { (feet) }\end{array}$} & \multirow{3}{*}{$\begin{array}{l}\text { Depth } \\
\text { of } \\
\text { well } \\
\text { (feet) }\end{array}$} & \multirow{3}{*}{$\mid \begin{array}{c}\text { Depth } \\
\text { to } \\
\text { water } \\
\text { (feet) }\end{array}$} & \multirow{3}{*}{ Aquifer } & \multirow{3}{*}{$\begin{array}{l}\text { Yield } \\
\text { (gpm) }\end{array}$} & \multirow{3}{*}{ Remarks } \\
\hline & \multirow{2}{*}{$\begin{array}{c}\text { Area } \\
\text { on } \\
\text { fig. } 1\end{array}$} & \multicolumn{2}{|c|}{ Section } & \multirow{2}{*}{$\mathrm{T}$. } & \multirow{2}{*}{ R. } & & & & & & & \\
\hline & & Quarter & No. & & & & & & & & & \\
\hline
\end{tabular}

Bureau of Land Management Bakersfield Grazing District

\begin{tabular}{|c|c|c|c|c|c|c|c|c|c|c|c|c|}
\hline 1 & 1 & $\ldots$ & 6 & $15 \mathrm{~N}$. & $17 \mathrm{E}$ & Karl Weikel & 4,070 & -1 & & Qal & & \\
\hline 2 & 3 & $N E$ & 24 & $13 \mathrm{~N}$. & $18 \mathrm{E}$ & V.G. Brown & 2,780 & & & Qal,Tv & & \\
\hline 3 & 4 & NW & 29 & $1 \mathrm{~N}$. & $29 \mathrm{E}$. & 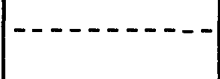 & 7,400 & & & $\begin{array}{l}\text { Qal, } \\
\text { QTV }\end{array}$ & $\ldots$ & $\begin{array}{c}\text { Large risk of } \\
\text { no water. }\end{array}$ \\
\hline S1 & 2 & $\mathrm{NE}, \mathrm{SW}$ & 16 & $12 \mathrm{~N}$. & $11 \mathrm{E}$ & Burro Holes & 2,960 & & 2 & Qal & & \\
\hline
\end{tabular}

\section{COLORADO}

\section{BY M. C. VAN LEWEN}

\section{BUREAU OF LAND MANAGEMENT GRAZING DISTRICT 8}

The Bureau of Land Management Grazing District 8 comprises parts of Saguache, Rio Grande, Conejos, and Alamosa Counties. Explorations for water in 1960 were made in northwestern San Luis Valley (1, fig. 1) where two well sites (D1, D2, table 3) were located. Wells weredrilled at these sites, but drilling was stopped at D1 before the estimated depth to water was reached. Recommendations for stock-water sources were based on field examinations by the author and a report by Powell (1958).

The area lies on each side of U.S. Highway 285 from 5 miles east of Saguache to 7 miles north of Villagrove. The western boundary is the bedrock hills that rise abruptly from the gently sloping alluvial valley fill, and the eastern boundary is the extent of public grazing land east of Highway 285, generally about 2 to 4 miles.

The north end of the San Luis Valley has been filled to a depth of several hundred feet with silt, sand, gravel, and boulders derived from the surrounding mountains and trans ported and deposited by streams flowing into the valley. This material, although poorly sorted and in some zones weakly cemented with calcium carbonate, is moderately permeable, and wells drilled below the level of the water table in the valley obtain adequate amounts of water for stock and domestic use. Many irrigation wells of high yield have been developed in this material in the central part of the valley.

The ground-water reservoir is recharged by perennial streams such as San Luis and Kerber Creeks, and by numerous small ephemeral streams. Its surface is probably parallel to the valley floor as in the central part of the valley (Powell, 1958). Wells drilled on alluvial fans at the mouths of ephemeral streams may obtain water at elevations somewhat above the regional water table.

Wells E1 and E2 (table 3) drilled into fractured igneous rock and volcanic ash beds, indicate that the zone of saturation extends from the valley fill into the surrounding bedrock.

\section{REFERENCE FOR COLORADO}

Powell, W.J., 1958, Ground-water resources of the San Luis Valley, Colorado: U.S. Geol. Survey Water -Supply Paper 1379. 
Table 3.-Well and spring locations examined or drilled in Colorado, 1960

[ $E$ with site number indicates existing well at time of examination; $D$ with site number indicates well drilled in 1960. Aquifers indicated by standard formation symbols: p€g, Precambrian granite; Qtf, compound alluvial fans and torrential wash]

\begin{tabular}{|c|c|c|c|c|c|c|c|c|c|c|c|c|}
\hline \multirow{3}{*}{$\begin{array}{l}\text { Site } \\
\text { No. }\end{array}$} & \multicolumn{5}{|c|}{ Location } & \multirow{3}{*}{ Name } & \multirow{3}{*}{$\begin{array}{c}\text { Eleva- } \\
\text { tion of } \\
\text { land } \\
\text { surface } \\
\text { (feet) }\end{array}$} & \multirow{3}{*}{$\begin{array}{c}\text { Depth } \\
\text { of } \\
\text { well } \\
\text { (feet) }\end{array}$} & \multirow{3}{*}{$\begin{array}{c}\text { Depth } \\
\text { to } \\
\text { water } \\
\text { (feet) }\end{array}$} & \multirow{3}{*}{ Aquifer } & \multirow{3}{*}{$\begin{array}{l}\text { Yield } \\
(\text { gpm) }\end{array}$} & \multirow{3}{*}{ Remarks } \\
\hline & \multirow{2}{*}{$\begin{array}{c}\text { Area } \\
\text { on } \\
\text { fig. } 1\end{array}$} & \multicolumn{2}{|c|}{ Section } & \multirow{2}{*}{ T. } & \multirow{2}{*}{ R. } & & & & & & & \\
\hline & & Quarter & No. & & & & & & & & & \\
\hline
\end{tabular}

Bureau of Land Management Grazing District 8

\begin{tabular}{|c|c|c|c|c|c|c|c|c|c|c|c|c|}
\hline $\mathrm{E} 1$ & 1 & NESE & 12 & $45 \mathrm{~N}$. & $8 \mathrm{E}$. & - & 8,240 & 170 & 26 & $p \in g$ & $\cdots$ & $\begin{array}{l}\text { Well aban- } \\
\text { doned. }\end{array}$ \\
\hline $\mathrm{E} 2$ & 1 & NWNE & 26 & $45 \mathrm{~N}$. & $8 \mathrm{E}$. & $\ldots \ldots$ & 7,960 & 173 & 98 & Qtf & $\ldots$ & \\
\hline E3 & 1 & SW & 11 & $46 \mathrm{~N}$. & $9 \mathrm{E}$. & $\ldots$ & 8,030 & 144 & 138 & Qtf & - & Do. \\
\hline $\mathrm{E} 4$ & 1 & $\mathrm{NE}$ & 34 & $47 \mathrm{~N}$. & $9 \mathrm{E}$. & $\ldots$ & 7,970 & 10 & 3 & Qtf & & Dug well. \\
\hline D1 & 1 & SESE & 32 & $47 \mathrm{~N}$. & $9 \mathrm{E}$. & Alexander & 8,400 & 380 & $\ldots$ & None & None & $\begin{array}{l}\text { Drilling } \\
\text { stopped at } \\
\text { less than the } \\
\text { estimated } \\
\text { depth to } \\
\text { water. Site } \\
\text { examined in } \\
1960 .\end{array}$ \\
\hline D2 & 1 & SWNW & 29 & $47 \mathrm{~N}$. & $9 \mathrm{E}$. & Bagwell _ _ & 8,270 & 115 & 40 & Qtf & $10+$ & $\begin{array}{l}\text { Site selected } \\
\text { in } 1960 .\end{array}$ \\
\hline
\end{tabular}

\section{MONTANA}

BUREAU OF LAND MANAGEMENT GRAZING DISTRICT 2

\section{BY M.C. VAN LEWEN}

The Bureau of Land Management Grazing District 2 comprises all of Garfield, McCone, and Dawson Counties and parts of Rosebud, Custer, and Prairie Counties. Explorations for water in 1960 were made in 3 areas (2-4, fig. 1) where 11 well sites were located. Information is given on one well drilled as a result of recommendations made in 1960 . Recommendations for stock-water sources were based on field examinations by C. E. Sloan and the author and on reports by Perry (1934, 1935), Dobbin and Erdman (1955), and Collier and Knechtel (1939).

Areas near Van Norman, Garfield County (1-3, table 4), near Weldon, McCone County (4, D2, table 4), and between Rock Springs and DeGrand, Prairie and Custer Counties (5-9, E6, table 4) were examined to select sites for wells. Although these areas are widely separated geographically, all are underlain by the Fort Union Formation of Paleocene age, and thus ground water occurs under similar conditions.

In eastern Montana the Fort Union Formation consists, from the base upward, of the Tullock, Lebo Shale, and Tongue River Members.

The Tullock Member averages about 250 feet in thickness and is predominantly dark clay shale, with lesser amounts of sandy shale and crossbedded sandstone. A few thin coal beds occur in the member. The Tullock contains enough permeable sandstone that a well drilled to a moderate depth has an excellent chance of obtaining adequate water suitable for stock use.

The Lebo Shale Member, which consists of about 300 feet of very dark clay shale and carbonaceous shale, contains some lenses and pockets of gray to buff crossbedded sandstone, but because these lenses are randomly distributed and make up only a small part of the total thickness of the Lebo Shale Member, there is some risk that a well drilled into 
this member will not obtain water. However, most wells drilled into the Lebo Shale Member in the areas under consideration have been successful.

The Tongue River Member consists of in tercalated beds of dark-gray to light-yellow shale, sandy shale, and sandstone. It is a very reliable aquifer that in this part of Montana it ranges in thickness from about 700 feet near Weldon (Collier and Knechtel, 1939) to about 1,200 feet near Mildred (Perry, 1935). However, because sandstones of this member grade laterally into sandy shale and shale, commonly in a short distance, it is difficult to predict closely the depth to water.

In each of the areas examined, water in the Fort Union Formation is under artesian pressure, and a rise of water in a drilled well, often a substantial part of the total depth, may be expected. Water obtained from the Tongue River Member generally contains less dissolved solids than does water from either the Tullock or Lebo Shale Member. So far as is known all water produced by wells tapping the Fort Union Formation is suitable for stock use.

BUREAU OF LAND MANAGEMENT GRAZING DISTRICT 3

$$
\text { BY M. C. VAN LEWEN }
$$

The Bureau of Land Management Grazing District 3 comprises all of Fallon and Carter Counties and parts of Prairie, Custer, and Powder River Counties. Explorations for water in 1960 were made in the Mildred area (5, fig. 1) where six well sites (10-15, table 4) were examined. Recommendations for stockwater sources were based on field examinations by C. E. Sloan and the author and reports by Perry (1935) and Dobbin and Larsen (1936).

The six well sites are grouped around the community of Mildred. All but the Severson site (15) are immediately underlain by gently folded beds of the Fort Union Formation of Paleocene age whose water-bearing characteristics are discussed under Grazing District 2 .

The Severson site is near the crest of the Cedar Creek anticline and is underlain by more than 1,000 feet of the Pierre Shale of Late Cretaceous age, which in this area does not yield adequate amounts of water suitable for stock use. In general, the prospects are unfavorable for the development of stock water from drilled wells near the crest of Cedar Creek anticline, which extends from Baker to Glendive. Water supplies may be developed, however, on the flanks of the anticline from wells drilled into sandstones in the Fox Hills and Hell Creek Formations both of Late Cretaceous age.

BUREAU OF LAND MANAGEMENT GRAZING DISTRICT 4

$$
\text { By N. J. KING }
$$

The Bureau of Land Management Grazing District 4 occupies part of Carbon County. Explorations for water in 1960 were made in 3 areas where 10 well sites were examined. Information was obtained on three wells (D3D5, table 4) that were drilled as a result of recommendations made in and before 1960 . Recommendations for stock-water sources were based on field examinations and study of the "Geologic Map of Montana" (Rose, Andrews, and Witkind, 1955) by the author.

\section{Belfry area}

Two well sites were selected in the moderately dissected upland area southwest of Belfry (6, fig. 1). Both sites are in ephemeral-stream valleys that are incised in interbedded sandstone and shale of the Fort Union Formation. The stream valleys commonly are sinuous, following neither the dip nor the strike of the beds. Consequently, sandstone beds that underlie dip slopes in one valley reach may be truncated and drained at some downstream point where the valley is incised across the dipping beds.

Except near the drainage divides where the slopes are steep and the opportunity for recharge to potential aquifers is limited, wells should yield suitable supplies of water for stock use. The depth to water may be expected to range considerably from one part of the area to another depending on the local stratigraphy and the balance between groundwater recharge and drainage as determined by the topography. At site 16 (table 4) the beds dip in the opposite direction from the land surface. Sandstone beds underlying the site should not be drained below the level where they crop out in the channel downstream from the site. This corresponds to a 
drilling depth of about 75 feet. Site 17 (table 4), however, is on a dissected dip-slope surface that, when traced southeastward along the strike of the beds, ends abruptly against the valley of the Clarks Fork Yellowstone River. Very likely, therefore, permeable beds underlying the site are drained to about the river level, which corresponds to a drilling depth of 220 feet.

\section{Elk Basin area}

Four well locations selected by the Bureau of Land Management were examined in October to determine the prospects of finding water. The locations under consideration ( 7 , fig. 1) are on the northeast flank of Elk Basin anticline where most streams flow in strike valleys cut in shale-one side steep, the other a dip-slope surface generally underlain by sandstone. Thus potential aquifers in the form of sandstone beds of Mesozoic and Tertiary age can be reached at comparatively shallow depths in most of the strike valleys. The drilling program to date shows the average depth to water on the valley floors to be less than 150 feet. The depth to water increases with increasing distance up the valley sides and very likely is excessive near the drainage divides. Yields of existing wells seldom exceed $20 \mathrm{gpm}$, and no wells yield water that is not suitable for stock use.

Sites 18-20 (table 4) are in strike valleys underlain by potential aquifers so that prospects of completing stock-water wells at these locations are believed to be good to excellent. Site 21 (table 4), however, is on the high surface of Polecat Bench about 2 miles southeast of the point where the thick sand stone bed that underlies the site crops out in the bottom of Hunter Creek canyon. The absence of a spring in the canyon at the outcrop indicates that the inferred aquifer may be drained in the vicinity of the site. Therefore, there is some risk of obtaining a dry hole.

\section{Pryor Mountain area}

To determine the prospects of finding water in the proximity of three locations $(22,23,25$, table 4) selected by the Bureau of Land Management, an examination was made of the foothills area along the south and west sides of Big Pryor Mountain (8, fig. 1).

Near site 23 (table 4) the beds have been truncated by an old. erosional surface into which canyons are again becoming deeply incised. As the dip of the beds is in the same direction, but at a greater angle than the slope of the land surface,progressively older for mations are exposed toward the mountain front. Consequently, runoff from the mountain crosses the outcrop areas of formations underlying the site, thus affording an excellent opportunity for recharge to beds capable of transmitting water. Despite the opportunity for recharge, however, drilling was not recommended as the site is underlain to a depth of more than a thousand feet by shale and limestone beds of Paleozoic age that are not considered to be water-bearing. An alternate site $(24$, table 4$)$ was selected farther west where water can be obtained from the Tensleep Sandstone of Pennsylvanian and Early Permian age. The depth to water and pumping lift arebased on data from wells E17 and D5 (table 4).

Site 22 (table 4) is on the east side of a strike valley eroded in southwestward dipping beds of Jurassic age. In most respects the setting is like that at site 24 (table 4) except that the inferred aquifer is sandstone in the Sundance Formation of Late Jurassic age. The main difference is that beds underlying the site are not recharged directly by runoff from the mountain because they are truncated around the margins of Black Butte dome, a small upwarp that lies between the site and the mountain front. In the absence of any wells or springs in the strike valley under consideration, the occurrence and depth to water can only be inferred.

Site 25 (table 4) is near the axis of Gypsum Creek syncline at the south end of Big Pryor Mountain. The site is underlain by interbedded sandstone and shale of the Chugwater Formation of Triassic age. A spring (S4, table 4) issues from a sandstone bed in the Chugwater Formation about half a mile northeast of and at a higher altitude than the site. It is virtually assured that water will be found in this sandstone bed at the site at about the estimated depth. The water will be high in mineral content, but like that of the spring, it should be suitable for watering stock.

\section{REFERENCES FOR MONTANA}

Collier, A.J., and Knechtel, M. M., 1939, The coal resources of MoCone County, Montana: U.S. Geol. Survey Bull. 905. 


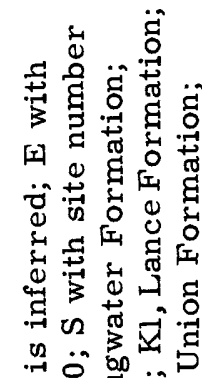

๕

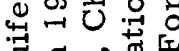

肎甜

व

寻告瓜文

施

\& $\rightarrow 20$

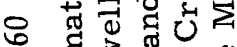

금

苟嵒吕峦焉

¿

สี न्वृ क्षे

मी

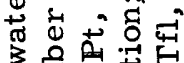

름

겨

동 क

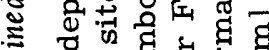

뎐

运的质

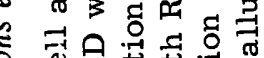

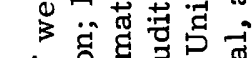

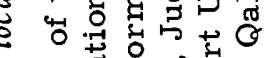

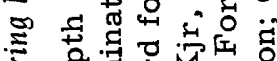

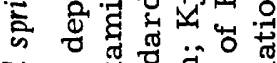

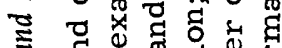

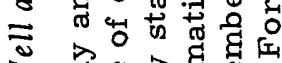

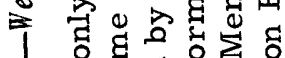

$\rightarrow$ O

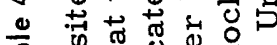

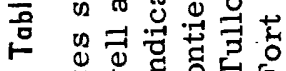

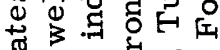

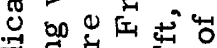

न.

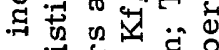

我范

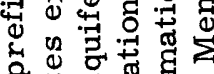

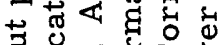

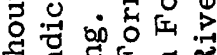

焉医红

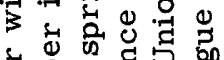

कै क

द्व 멸 茫

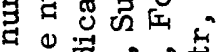

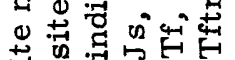

范

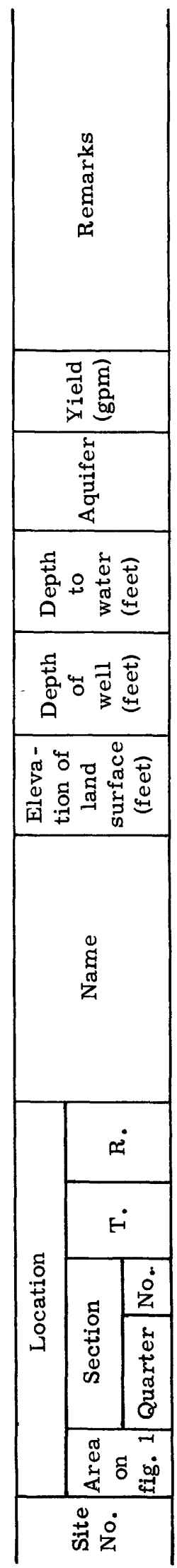

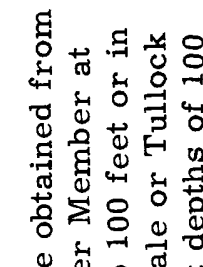

๑正。范范.

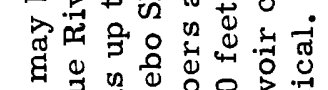

मे

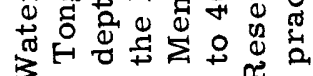

$=1$

$+$

3

$\exists$

वे

放

वं

范

훙ํํ

苂

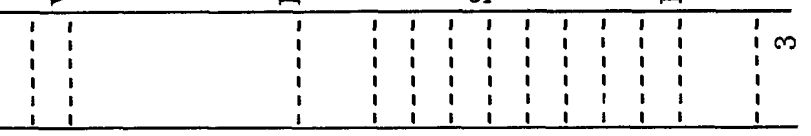

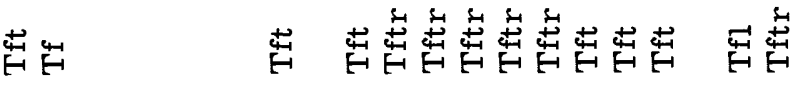

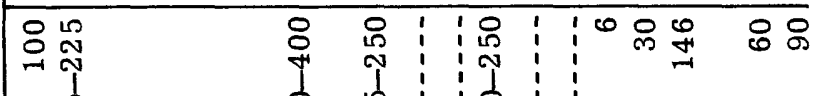

న

家家

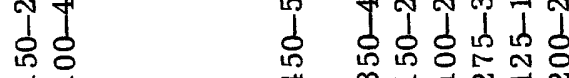

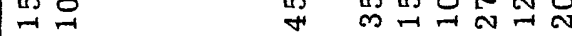

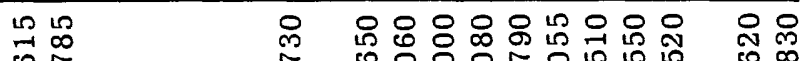

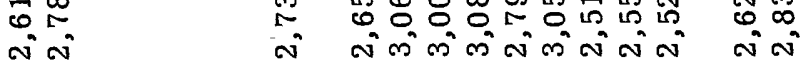

\begin{tabular}{|c|c|c|c|}
\hline 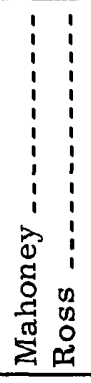 & 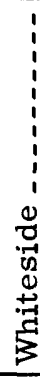 & 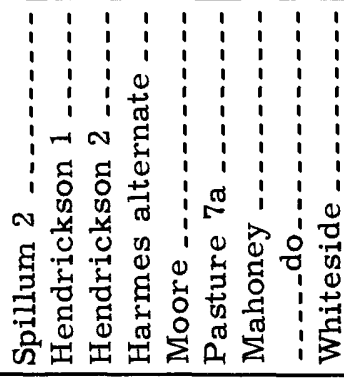 & 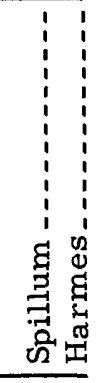 \\
\hline 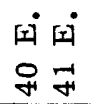 & $\begin{array}{l}\text { 19i } \\
m \\
+\end{array}$ & 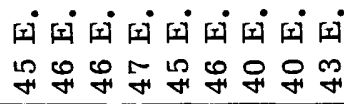 & 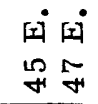 \\
\hline $\begin{array}{l}\dot{z} \dot{z} \\
\infty=\infty\end{array}$ & zi & 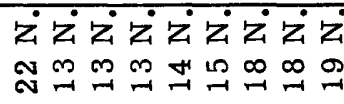 & $\begin{array}{l}\dot{z}{ }^{2} \\
\text { N } \rightarrow\end{array}$ \\
\hline$\omega$ & & $0+$ & \\
\hline
\end{tabular}

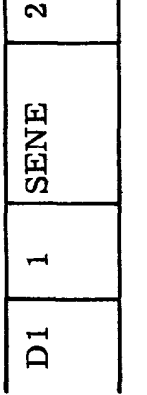

\begin{tabular}{|c|c|c|}
\hline 觉畋 & $\frac{3}{n}$ & 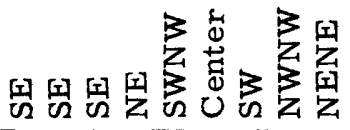 \\
\hline ก ก & $\mathbf{N}$ & $m \pi$ m H N N N \\
\hline$\rightarrow N$ & $m$ & 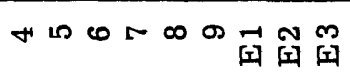 \\
\hline
\end{tabular}




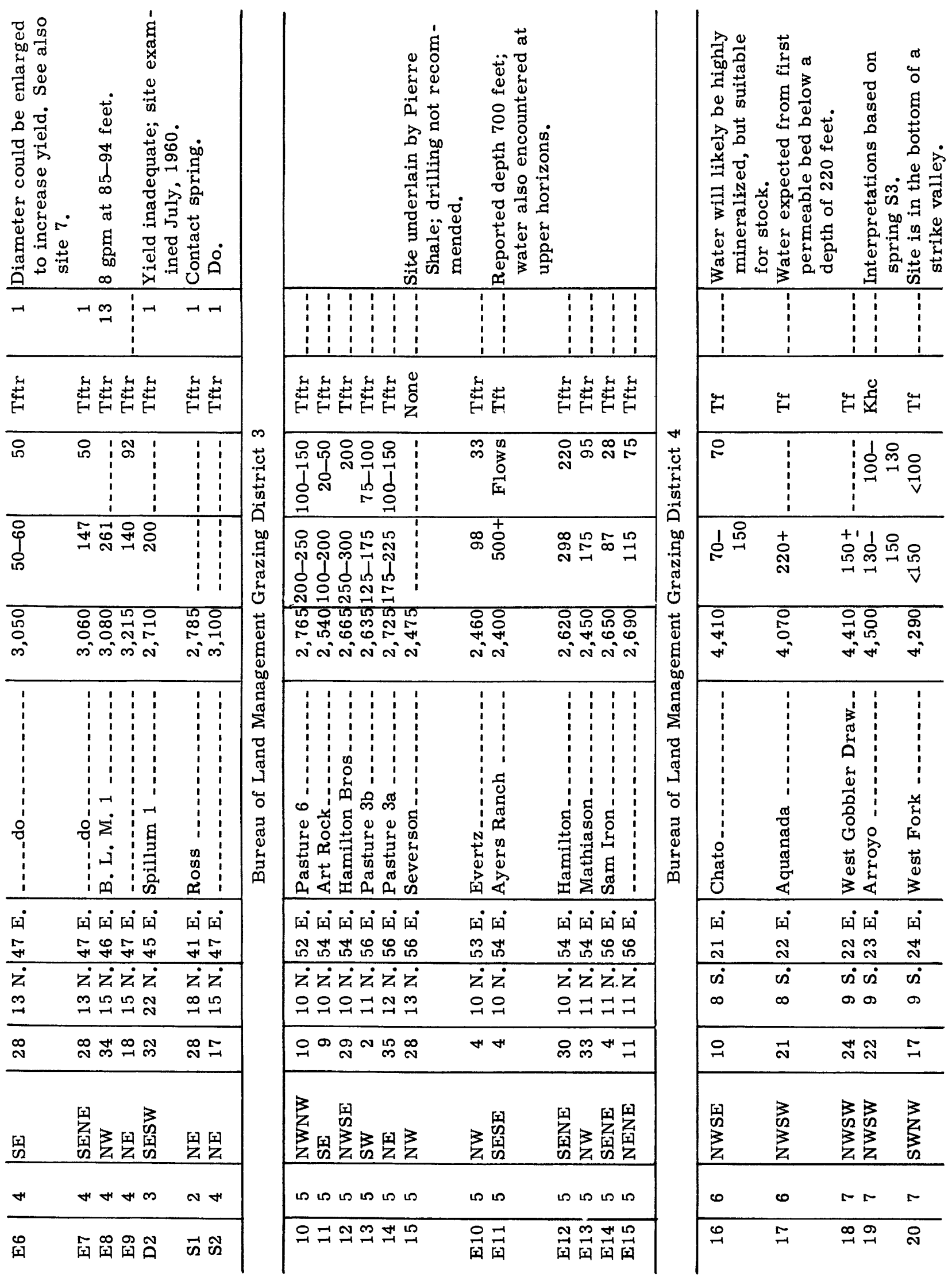


EXPLORATIONS FOR WATER SUPPLIES ON THE PUBLIC DOMAIN, 1960

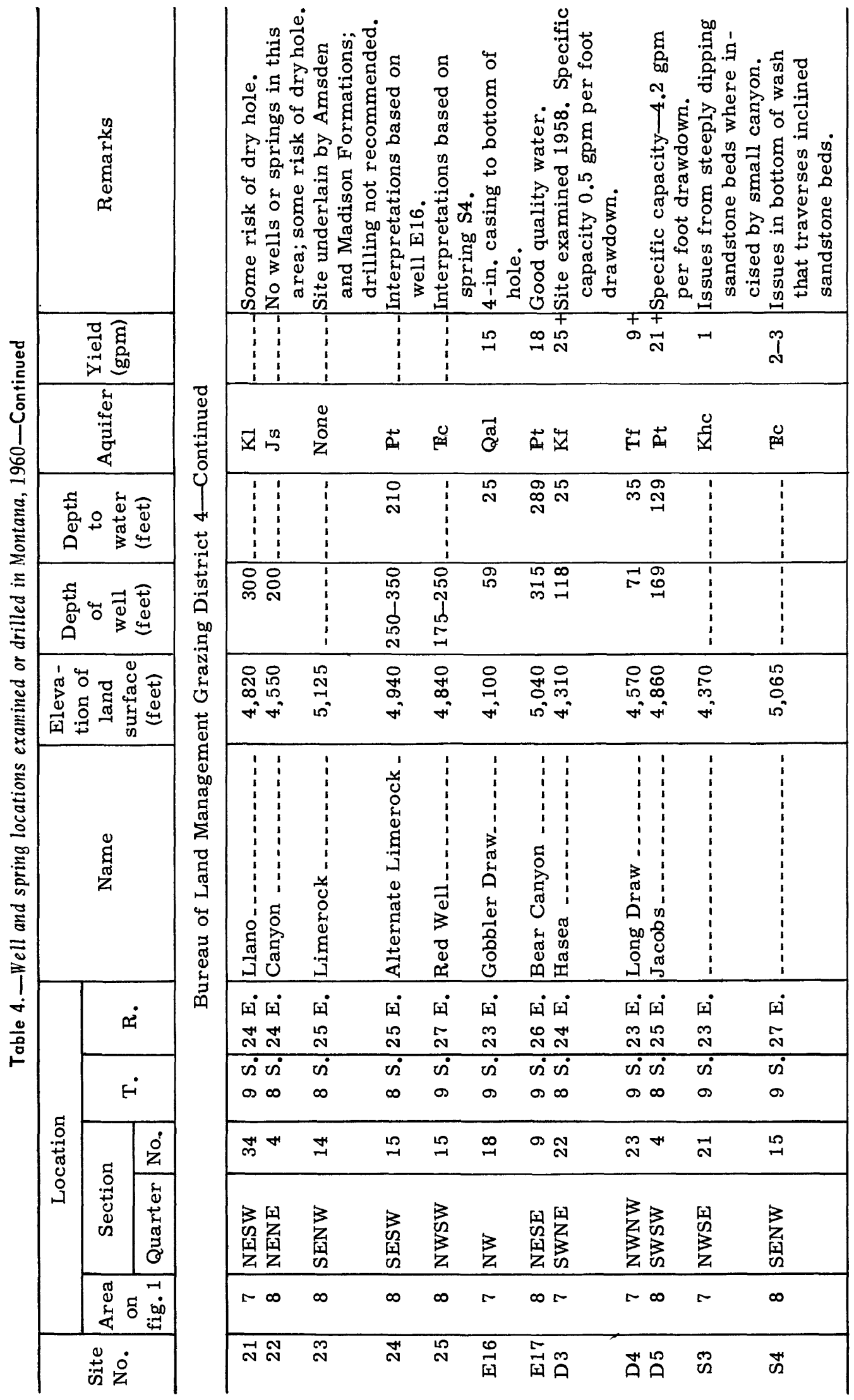


Dobbin, C. E., and Erdmann, C. E., 1955, Structure contour map of the Montana plains: U.S. Geol. Survey Oil and Gas Inves. Map OM 178.

Dobbin, C. E., and Larsen, R. M., 1936, Geologic and structure contour map of the Cedar Creek anticline, Dawson, Prairie, Wibaux, and Fallon Counties, Montana, and Bowman County, North Dakota: U.S. Geol. Survey General Mineral Resource Map.

Perry, E. S., 1934, Geology and artesian water resources along Missouri and Milk Rivers in northeastern Montana: Montana State Bur. Mines and Geology Mem. 11.

-1935, Geology and ground-water resources of southeastern Montana: Montana State Bur. Mines and Geology Mem. 14.

Ross, C. P., Andrews, D. A., and Witkind, I. J., 1955, Geologic Map of Montana: U.S. Geol. Survey, scale, 1:500,000.

\section{NEVADA}

\section{BY C. T. SNYDER}

\section{BUREAU OF LAND MANAGEMENT ELKO GRAZING DISTRICT}

The Elko Grazing District includes all of Elko County and parts of Eureka and Lander Counties. Explorations for water in 1960 were made in four widely scattered areas where four well sites were examined. Information on wells drilled as a result of recommendations in 1960 or previous years (wells D4 and D5) is given in table 5. Recommendations for stock-water sources were based on field examinations by the author and F. F. Zdenek of the Geological Survey and reports by Hains, Van Sickle, and Ryals (1949), and Granger and others (1957).

\section{Wendover area}

The valley northwest of Wendover ( 3 ,fig. 1 ) was visited in September, and well site D1 (table 5) was selected on the flank of the Toana Mountains. The location considered to be the most favorable for exploratory drilling was high up on the valley edge in the mouth of a small embayment, known locally as Morris Basin. Alluvium from the basin has accumulated here, being held in place by relic terraces left by the Pleistocene Lake Bonneville. It was anticipated that water might be moving out of the mountains eastward toward the alluvium-filled valley. This site was subsequently drilled and abandoned after 90 feet of alluvium-overlying bedrock-was found to be non-water-bearing.

\section{Salmon Falls River area}

Salmon Falls River area (2, fig. 1) was visited in September by F. F. Zdenek who selected site 1 (table 5) along a dry wash that is tributary to the Salmon Falls River. In this area the river occupies a fault-formed valley that has been filled with fluvial and lacustrine deposits that are part of the Humboldt Formation of (Miocene and Pliocene (?)) Tertiary age. In places Quaternary alluvial deposits overlie the Humboldt Formation. These formations are almost everywhere permeable and are aquifers in nearby areas. Zdenek visited well E2 (table 5) which had water at a reported depth of 87 feet. Differences in elevation between this well and the proposed site make it appear that drilling may have to be continued to a depth of 600 feet unless shallower permeable beds are discovered.

\section{Susie Creek Valley}

Susie Creek Valley (4, fig. 1) was visited in September, and well site D2 (table 5) was located in a narrow, tributary valley about a mile east of Susie Creek. Susie Creek and its tributaries have trenched the Humboldt Formation exposing several hundred feet of lacustrine sediments, largely silt and clay, interbedded with thick accumulations of water-laid volcanic ash. The Humboldt Formation is widely distributed in northeastern Nevada and is usually water bearing at or slightly above the level of the master stream. A well was drilled at the selected location, and water was reached at 65 feet, which is slightly above the level of Susie Creek.

\section{Boulder Valley}

The Boulder Valley area (1, fig. 1 ) was vis ited in June, and well site D3 (table 5) was selected on the valley floor to replace well E1 which was dry. Boulder Valley appears to have been formed by a meander of the Humboldt River that cut northward into the Tuscarora Mountains. This valley and the valley of the Humboldt River are filled with a continuous body of saturated alluvium. After the examination in June the well was drilled and an adequate supply of water obtained from an aquifer whose top is at a depth of 146 feet. 


\section{BUREAU OF LAND MANAGEMENT PYRAMID GRAZING DISTRICT}

The Pyramid Grazing District includes all of Humboldt County and parts of Pershing and Washoe Counties. Explorations for water in 1960 were made in four rather widely spaced areas and eight well sites were examined. Information on five wells drilled as a result of recommendations made in 1960 and previous years is given in table 5. Recommendations for stock-water sources were based on field examinations by the author and F. F. Zdenek of the Geological Survey and a report by Peterson (written communication, 1945).

\section{Quinn River Valley}

Quinn River Valley (7, fig. 1) was visited first in July and later in November and four well sites (4, D6, D7, and D9, table 5) were selected for drilling into the valley alluvium. Quinn River Valley is a sprawling downdropped valley surrounded by mountains. The valley alluvium is hundreds to thousands of feet thick in the valley center and a few tens of feet thick on the valley margins. Alluvial fans form a transition zone between the mountains and the valley. Older rocks of the down-dropped block underlie the valley fill. Unless it contains thick bodies of clay or silt the valley fill usually is permeable and contains ground water that moves from the mountains toward the valley center. Permeability throughout the valley fill is not uniform as the formation is a heterogeneous mixture with layers of coarse (permeable) material interbedded with the impermeable, fine-grained, sediments. The geology and hydrology of Quinn River Valley are characteristic of most valleys of the Pyramid Grazing District. Ground water occurs at varying depths in the valley fill of Quinn River Valley and most wells attempted in the valley have been successful except where there is shallow bedrock. Three wells, D6, D7, and D9, have been drilled to date (May 1961). Of these, the well at site D9 had water at 75 feet and the drilling at sites D6 and D7 has been temporarily suspended.

\section{Desert Valley}

Desert Valley (8, fig. 1) is an alluviumfilled valley that is parallel to and just west of Quinn River Valley. Unlike Quinn River Valley-where the river flows down the length of the valley-Desert Valley is crossed by the Quinn River from east to west. This valley was visited in July and well site D8 (table 5) was selected on its northern edge. Ground water is moving through the valley fill from the mountains toward the Quinn River, and well site D8, selected on this basis, was drilled in the fall of 1960 . Water came into the well at a depth of 52 feet but stands in the completed well at a depth of 30 feet below ground surface.

\section{Trinity Range}

The Trinity Range (10, fig. 1), a system of low hills west of Lovelock, was visited in July and well site D10 (table 5) was selected for drilling into the alluvium along a dry wash. In the area examined, the Quaternary alluvium of the streambed overlies Tertiary basalt flows with interbedded layers of tuff. These formations are water bearing in other areas, and exploratory drilling here was believed to be justified on the dual basis of potential aquifers and need for water. The well was drilled in a nearby canyon having a similar geologic setting and was abandoned, dry, at 390 feet.

\section{Black Rock Desert}

The Black Rock Desert area was visited in July and two widely separated well sites (2, 3 , table 5) were examined. Site 2 was selected at a location along an unnamed dry stream channel in the mountains east of the Black Rock Desert. The alluvium of the stream channel is a narrow thread of permeable material underlain by generally impermeable bedrock. The channel, extending several miles north of the proposed site, may have water moving as underflow toward Black Rock Desert. Water is found in simi lar conditions in many places throughout the the surrounding valleys and may logically be expected here.

Site 3 was selected on the edge of Black Rock Desert about 25 miles northwest of site 2. This part of the desert is an embayment north of the main desert and west of the Black Rock Range. It is an alluvial-filled basin with alluvial fans around the valley edge. Water should occur at a shallow depth either in the alluvial fan or in the underlying valley fill. 


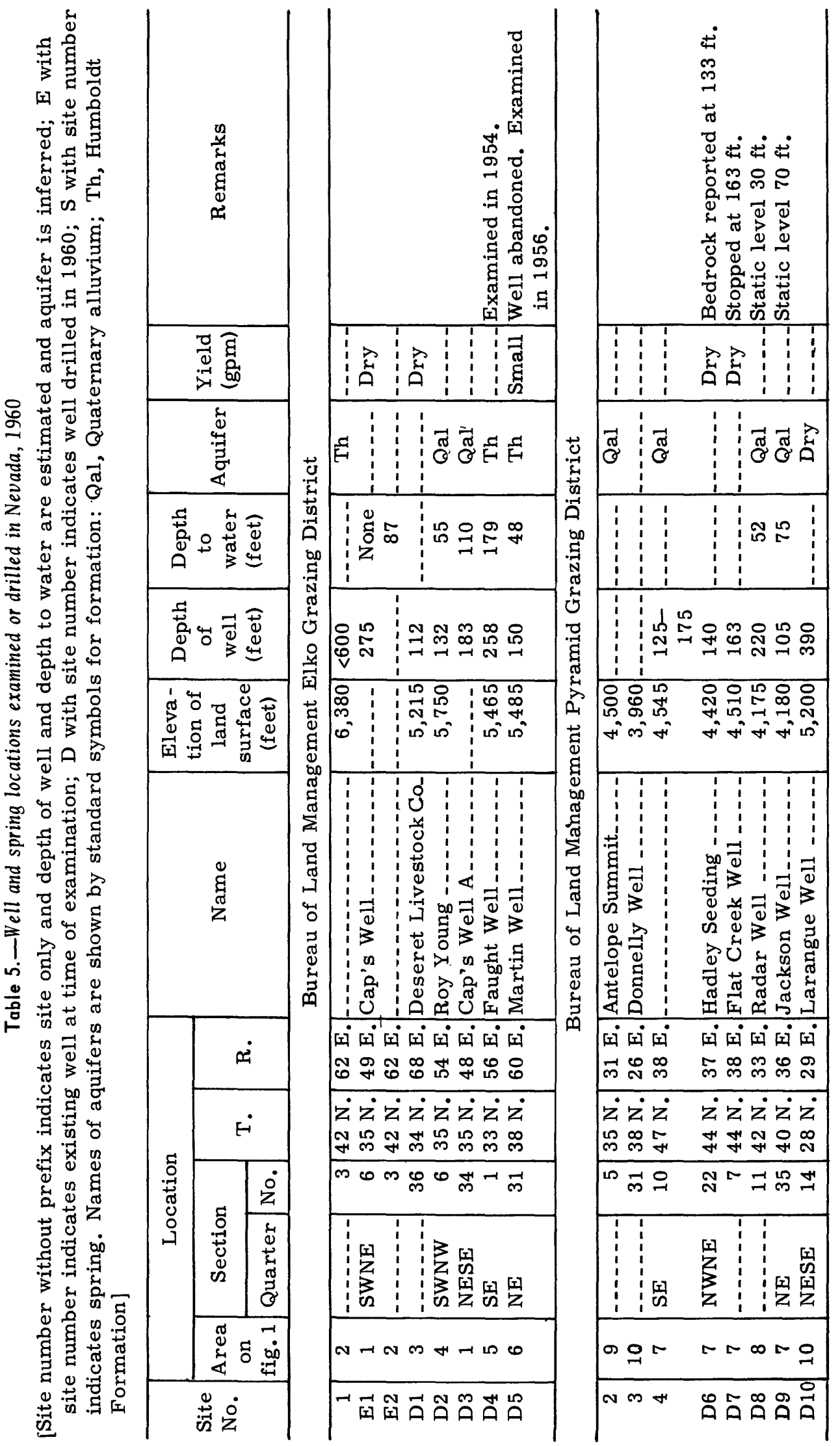




\section{REFERENCES FOR NEVADA}

Hains, C. F., Van Sickle, D. M., and Ryals, W. G., 1949, Range water resources of a part of the Elko Grazing District, Elko County, Nevada: U.S. Geol. Survey openfile rept., $84 \mathrm{p}$.

Granger, A. E., Bell, M. M., Simmons, G. E., and Lee, F., 1957, Geology and mineral resources of Elko County, Nevada: Nevada Bur. Mines Bull. 54, 189 p.

\section{OREGON}

\section{By C. T. SNYDER}

\section{BUREAU OF LAND MANAGEMENT VALE GRAZING DISTRICT}

The Vale Grazing District includes all of Malheur County. Explorations for water in 1960 were made in four areas where seven well sites were examined. Information on seven wells drilled as a result of recommendations made in 1960 and previous years is given in table 6. Recommendations for stockwater sources were based on a field examination by the author and on a report by Baldwin (1959).

\section{Rattlesnake Creek area}

This area $(1$, fig. 1$)$ was visited in September 1959 and in July 1960, and two well sites $(1, D 1$, table 6) were selected. Site D1 is on a sagebrush-covered flat near the edge of Rattlesnake Creek and beside a dry stream channel coming from the east. Rattlesnake Creek occupies an alluvium-filled valley that has been cut in flat-lying older rocks. The alluvium is a widespread but fairly thin deposit, largely restricted to the valley bottom, and underlain by a sequence of Tertiary volcanic rocks and lacustrine sediments. These rocks, consisting of tuffaceous siltstone and sandstone with interbedded basalt flows, occur over much of the area east and south of U.S. Highway 95. Their water-bearing properties are not well established, but in other areas similar rocks are known to be permeable and will yield enough water for stock. Water occurs as underflow in the alluvium of Rattlesnake Creek, usually less than 1 foot below the surface. Wells E1 and E2 (table 6) are in this alluvium. It was concluded that water was moving from the southeast and east toward Rattlesnake Creek. A well was drilled at site D1 and water was reached at a depth of 295 feet.
Site 1 is on the south edge of the valley about 5 miles southwest of site D1 where a well drilled into the alluvium (of the same valley) should be successful.

\section{East side of the Owyhee River}

This area (2, fig. 1 ) was visited in July 1960 and three locations (2-4, table 6) were examined. The area east of the Owyhee River between sites 2 and 3 is underlain by flatlying beds of lava and volcanic ash that have been deposited over older volcanic rock that has been tentatively identified as rhyolite. The flat-lying beds above the rhyolite are permeable and carry water at or below the level of the river. The rhyolite is exposed only at scattered locations in the canyon walls. It is believed that the flat-lying beds were deposited over an old land surface of moderate relief, which had been formed on the rhyolite. The ryholite is usually massive and is not known to be water bearing. Limited occurrences of Quaternary alluvium are found on top of the flat-lying beds of lava and volcanic ash. These bodies of alluvium are small and may or may not contain water. Site 2 was recommended for exploratory drilling into beds underlying a lava-capped plateau between the Owyhee River and Jordon Creek. A well drilled here probably will be successful unless the rhyolite is above river level, in which case the chances for obtaining water are small. The estimated drilling depth is 400 to 500 feet.

Sites 3 and 4 are on a lava-capped plateau east of the Owyhee River Canyon. A large body of rhyolite is exposed in the canyon where the river has cut through several hundred feet of the non-water-bearing material. Site 3 was rejected because the rhyolite exposed in the canyon nearby very likely extends under this site. Moreover, the total drilling depth to river level, about 1,200 feet, is prohibitive. Site 4 was selected as a place to explore the shallow alluvial fill of a small closed basin lying just east of the Owyhee Canyon. No other well sites appear feasible so exploratory drilling at this location may be justified. The alluvial fill here probably is not thick. Deeper drilling into the rocks underlying the alluvium is not justified.

\section{Oregon Canyon Creek}

Oregon Canyon Creek ( 3 , fig. 1 ) is a southward-flowing, ephemeral stream in the northern end of the Quinn River Valley. Well site 5 
Table 6.-Well and spring locations examined or drilled in Oregon, 1960

[Site number without prefix indicates site only and depth of well and depth to water are estimated and aquifer is inferred; $E$ with site number indicates existing well at time of examination; D with site number indicates well drilled in 1960. Names of aquifers are shown by standard symbols for formations: Qal, Quaternary alluvium; Tv, Tertiary volcanic rocks, undifferentiated]

\begin{tabular}{|c|c|c|c|c|c|c|c|c|c|c|c|c|}
\hline \multirow{3}{*}{$\begin{array}{l}\text { Site } \\
\text { No. }\end{array}$} & \multicolumn{5}{|c|}{ Location } & \multirow{3}{*}{ Name } & \multirow{3}{*}{$\begin{array}{l}\text { Eleva- } \\
\text { tion of } \\
\text { land } \\
\text { surface } \\
\text { (feet) }\end{array}$} & \multirow{3}{*}{$\begin{array}{l}\text { Depth } \\
\text { of } \\
\text { well } \\
\text { (feet) }\end{array}$} & \multirow{3}{*}{$\begin{array}{l}\text { Depth } \\
\text { to } \\
\text { water } \\
\text { (feet) }\end{array}$} & \multirow{3}{*}{ Aquifer } & \multirow{3}{*}{$\begin{array}{l}\text { Yield } \\
\text { (gpm) }\end{array}$} & \multirow{3}{*}{ Remarks } \\
\hline & \multirow{2}{*}{$\begin{array}{l}\text { Area } \\
\text { on } \\
\text { fig. } 1\end{array}$} & \multicolumn{2}{|c|}{ Section } & \multirow{2}{*}{ T. } & \multirow{2}{*}{ R. } & & & & & & & \\
\hline & & Quarter & No. & & & & & & & & & \\
\hline
\end{tabular}

Bureau of Land Management Vale Grazing District

\begin{tabular}{|c|c|c|c|c|c|c|c|c|c|c|c|c|}
\hline 1 & 1 & $\mathrm{SE}$ & 21 & $35 \mathrm{~S}$. & $41 \mathrm{E}$. & & 4,125 & & $\ldots$ & Qal & & \\
\hline 2 & 2 & NENE & 35 & $30 \mathrm{~S}$. & $41 \mathrm{E}$. & $\ldots$ & 3,900 & $\begin{array}{r}400- \\
500\end{array}$ & $\ldots$ & $\mathrm{Tv}$ & $\ldots$ & \\
\hline 3 & 2 & $\ldots$ & 6 & $33 \mathrm{~S}$. & $45 \mathrm{E}$. & $\ldots \ldots$ & 4,700 & $\ldots \ldots$ & $\ldots$ & $\mathrm{Tv}$ & 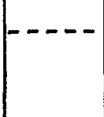 & $\begin{array}{l}\text { Drilling not } \\
\text { recom- } \\
\text { mended. }\end{array}$ \\
\hline 4 & 2 & SW & 35 & $32 \mathrm{~S}$. & $44 \mathrm{E}$. & $\ldots$ & 4,620 & $\cdots$ & $\begin{array}{c}\text { Shal- } \\
\text { low }\end{array}$ & Qal & 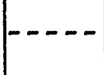 & \\
\hline 5 & 3 & Center & 18 & $38 \mathrm{~s}$. & $41 \mathrm{E}$. & & 4,850 & $<100$ & $\ldots$ & Qal & & \\
\hline 6 & 4 & $\ldots \ldots$ & 1 & $36 \mathrm{~S}$. & $37 \mathrm{E}$. & 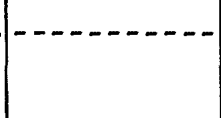 & 4,300 & $\begin{array}{r}100- \\
200\end{array}$ & . & Qal & & $\begin{array}{l}\text { Place where } \\
\text { water is } \\
\text { needed most. }\end{array}$ \\
\hline $\mathrm{E} 1$ & 1 & SE & 13 & $35 \mathrm{~S}$. & $41 \mathrm{E}$. & D. Bankofier & 4,100 & $\ldots$ & 7 & Qal & $\ldots$ & \\
\hline E2 & 1 & NENE & 27 & $34 \mathrm{~S}$. & $41 \mathrm{E}$. & $\begin{array}{l}\text { Bowden } \\
\text { Ranch. }\end{array}$ & 3,925 & 12 & 7.0 & Qal & $\ldots$ & \\
\hline E3 & 3 & SW & 28 & $38 \mathrm{~S}$ & $41 \mathrm{E}$. & $\begin{array}{l}\text { School } \\
\text { House Well }\end{array}$ & 4,870 & & 7.71 & Qal & & \\
\hline $\mathrm{E} 4$ & 3 & $\mathrm{NE}$ & 32 & $38 \mathrm{~s}$. & $41 \mathrm{E}$. & Echave Bros & 4,885 & $\ldots$ & 9.4 & Qal & $\ldots$ & \\
\hline E5 & 4 & SW & 11 & $36 \mathrm{~S}$. & $36 \mathrm{E}$. & $-\ldots$ & 4,180 & $\ldots \ldots$ & $<10$ & Qal & $\ldots$ & \\
\hline D1 & 1 & SW & 6 & $35 \mathrm{~S}$. & $42 \mathrm{E}$. & Grafton Well & 4,050 & 315 & 295 & $\mathrm{Tv}$ & $\ldots$ & \\
\hline
\end{tabular}

Bureau of Land Management Prineville Grazing District

\begin{tabular}{|c|c|c|c|c|c|c|c|c|c|c|c|c|}
\hline 7 & 5 & $\mathrm{SE}$ & 14 & $23 \mathrm{~S}$. & $21 \mathrm{E}$. & $\ldots-1$ & 4,540 & $\ldots \ldots$ & $\ldots$ & $\mathrm{Tv}$ & $\ldots$ & \\
\hline 8 & 5 & $\ldots \ldots$ & 27 & $23 \mathrm{~S}$. & $21 \mathrm{E}$. & -- & 4,510 & $\ldots$ & & Qal,Tv & $|\ldots-|$ & \\
\hline 9 & 5 & NW & 28 & $23 \mathrm{~S}$. & $21 \mathrm{E}$. & $\ldots . .$. & 4,600 & $\ldots \ldots$ & $\ldots$ & Qal,Tv & $\ldots$ & \\
\hline 10 & 5 & SW & 30 & $23 \mathrm{~S}$. & $21 \mathrm{E}$. & 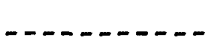 & 4,820 & $\ldots \ldots$ & $\ldots$ & $\mathrm{Qal}, \mathrm{TV}$ & $\ldots$ & \\
\hline 11 & 5 & SW & 23 & $23 \mathrm{~S}$. & $20 \mathrm{E}$. & - & 4,810 & $\ldots \ldots$ & $\ldots$ & Qal,Tv & $\ldots \ldots$ & \\
\hline 12 & 5 & $\ldots$ & 3 & $23 \mathrm{~S}$. & $20 \mathrm{E}$. & - & 4,550 & $\ldots \ldots$ & $\ldots$ & Qal,Tv & $\ldots$ & \\
\hline 13 & 6 & NENW & 30 & $21 \mathrm{~S}$. & $21 \mathrm{E}$. & $\ldots$ & 4,950 & $\ldots \ldots$ & $\ldots$ & Qal,Tv & $\cdots$ & \\
\hline 14 & 7 & NW & 30 & $19 \mathrm{~S}$. & $16 \mathrm{E}$. & - & 4,400 & $\ldots \ldots$ & - & Qal,Tv & $-\cdots$ & \\
\hline 15 & 7 & SW & 13 & $19 \mathrm{~S}$. & $15 \mathrm{E}$. & $\ldots$ & 4,420 & $\ldots \ldots$ & - & Qal,Tv & --- & \\
\hline 16 & 7 & NW & 18 & $19 \mathrm{~S}$. & $16 \mathrm{E}$. & $\ldots$. & 4,590 & 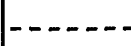 &.- & $\mathrm{Tv}$ & & \\
\hline 17 & 7 & NW & 21 & $19 \mathrm{~S}$. & $16 \mathrm{E}$. & $\ldots$ & 4,550 & $\ldots$ & & $\mathrm{Qal}, \mathrm{Tv}$ & & \\
\hline 18 & 7 & $\ldots \ldots$ & 15 & $19 \mathrm{~S}$. & $16 \mathrm{E}$. & $\ldots$ & 4,660 & $\ldots$ & $\ldots$ & $\ldots-$. & $\ldots$ & $\begin{array}{l}\text { Drilling not } \\
\text { recom- } \\
\text { mended. }\end{array}$ \\
\hline E6 & 5 & $\mathrm{NE}$ & 19 & $23 \mathrm{~S}$. & $20 \mathrm{E}$. & & & $\cdots$ & 120 & Qal & F- & \\
\hline E7 & 6 & SWSW & 19 & $21 \mathrm{~S}$. & $21 \mathrm{E}$. & & 6,050 & $<15$ & $\ldots$ & Qal & $\ldots$ & \\
\hline E8 & 7 & $\ldots \ldots$ & 14 & $19 \mathrm{~S}$. & $16 \mathrm{E}$. & & & -- & 850 & & $\ldots$ & - \\
\hline
\end{tabular}


(table 6) lies beside an unnamed tributary of Oregon Canyon Creek. This part of the Quinn River Valley is filled with alluvium that contains water at a fairly shallow depth as shown by two nearby wells (E3, E4, table 6) in both of which water stands at less than 10 feet below ground surface. Water probably is moving southward through the alluvium from the mountains toward Quinn River Valley.

\section{Whitehorse Ranch basin}

Well site 6 (table 6) is in a small closed basin known informally as the Whitehorse Ranch basin (4, fig. 1). This basin has no known outlet to nearby valleys. The valley has been filled with a considerable thickness of alluvium. Surface water enters the basin from hills to the south and southeast through a well-defined drainage system, but most of it goes into the ground near the southern edge of the valley where the valley floor is covered with sand dunes that absorb water rapidly. Water should be found here at less than 100 feet below the surface.

\section{BUREAU OF LAND MANAGEMENT PRINEVILLE GRAZING DISTRICT}

The Prineville Grazing District comprises parts of Crook, Deschutes, and Lake Counties. Explorations for water were made in October 1960 for 12 well sites (table 6). Recommendations for stock-water sources were based on a field examination by F.F. Zdenek of the Geological Survey and reports by Baldwin (1959), Bowman ${ }^{1}$, Lowry ${ }^{2}$, and Russell (1905).

Dry River valley area

The Dry River valley area in central Oregon was visited by Zdenek in October, at which time seven well sites were examined near Hampton and five were examined near Millican. Geologically this part of central Oregon is a transition zone wherein the rocks of the Columbia Plateau are broken by faults of the Great Basin type. Rocks underlying the area consist of basaltic and andesitic lava flows with interbedded tuff and agglomeate. Locally alluvium has accumulated in some of the fault -enclosed valleys. Continuity of the volcanic formations has been interrupted by numerous high-angle normal

1Bowman, F. J., 1940, Geology of the nouth half of the Hampton quadrangle, Oregon: Oregon State College, unpublished masters thesis.

${ }^{2}$ Lowry, W. D. , 1940, Geology of the Bear Creek area, Crooks and Deschutes County, Oregon: Oregon State College, unpublished masters thesis. faults that have a northwestward trend across the area. Water has been obtained by digging or drilling wells into the surficial alluvium and deeper drilling into-but not through-the underlying beds of lava and volcanic ash. Marked differences in depth to water between neighboring wells-both of which are drilled to water in the volcanic rocks-are commonplace; differences as great as 200 feet have been reported. These differences are caused by faults offsetting the water-bearing beds. It is possible that water may occur in the alluvium at sites 8-13 in the Hampton area and at sites 14, 15, and 17 in the Millican area. If water does not occur near the base of the alluvium, the possibility still remains that water may be found at depth in the volcanic rocks.

\section{REFERENCES FOR OREGON}

Baldwin, F. M., 1959, Geology of Oregon: Oregon Univ. Press, $136 \mathrm{p}$.

Russell, I. C., 1905, Geology and water resources of central Oregon, U.S. Geol. Sur vey Bull. 252, 138 p., 24 pls.

\section{UTAH}

\section{By CHARLES E. SLOAN}

Grazing Districts 6 and 9 are in San Juan and Grand Counties, Utah, respectively. Exploration for water in 1960 was made in five areas where nine well sites were located. Recommendations for stock-water sources were based on field examinations by the author and M. C. Van Lewen.

\section{BUREAU OF LAND MANAGEMENT GRAZING DISTRICT 6}

\section{The Bluff area}

The Bluff area (1, fig. 1) is north of the San Juan River in the vicinity of the town of Bluff and extends from Butler Wash on the west to Recapture Creek on the east. Sites 1 and 2 (table 7) were selected on Bluff Bench, a mesa underlain by the Bluff Sandstone that extends from Cottonwood Creek to Recapture Creek. Sites 3 and 4 were selected on Tank Mesa, a counterpart of Bluff Bench, that extends from Butler Wash to Cottonwood Creek. The formations in this general area dip gently eastward from Comb Ridge monocline 
toward the Sage Plains downwarp. Springs of low discharge (S1-S3, table 7) occur in most of the canyons that dissect the mesa indicating that thereis a thinbody of perched ground water in the basal part of the Bluff Sandstone of Late Jurassic age. The underlying Summerville Formation of Late Jurassic age is a relatively impermeable barrier that retards or prevents the downward movement of ground water.

\section{Lime Ridge area}

The Lime Ridge area (2, fig. 1 ) is in the rugged canyon country north of the San Juan River between Comb Wash and Lime Creek. Water is needed (site 5, table 7) on an anticline more than a thousand feet above the level of the nearby San Juan River. In addition to the unfavorable topographic and structural setting of the site, the general area is underlain to a considerable depth by the relatively impermeable Cutler (Permian age) and Rico (Pennsylvanian and Permian(?) age) Formations. Electric and radioactivity logs of Pan American Petroleum Corp. Lime Ridge No. 1 oil test about a mile east of the site show no indication of water-bearing beds to a depth of about 1,500 feet.

\section{Red House area}

The Red House area (3, fig. 1 ) is near the head of Steer Gulch at the northern end of Grand Gulch Plateau where the broad plateau surface abuts the higher surface of Red House Mesa. Well-site 6 (table 7) was selected on the plateau surface just north of Clay Hills Road in a small erosional reentrant in the mesa.

Grand Gulch Plateau is underlain by the Cedar Mesa Sandstone Member of the Cutler Formation, which locally reaches an estimated thickness of 900 feet. Three small springs ( $\mathrm{S} 4-\mathrm{S} 6$, table 7) issue above a shale parting in the sandstone at the head of Grand Gulch and are interpreted as an indication of perched water. Electric and radioactivity logs from the Southern Union Oil Co. Federal No. 1 oil test well in sec. 22 , T. 38 S., R. 16 E., also suggest that water may be obtained from this perched zone in the Cedar Mesa Sandstone Member. This zone would be reached at the proposed site at a depth of about 475 feet.

\section{Harts Point area}

Harts Point (4, fig. 1) is a high, elongate, northwest trending finger of land between the canyons of Harts Draw and Indian Creek about 15 miles east of the confluence of the Colorado and the Green Rivers. Harts Point is immediately underlain by the Navajo Sandstone which dips about $1^{\circ} \mathrm{NE}$ toward Harts Draw. The Navajo Sandstone (Triassic(?) and (Jurassic) in turn is underlain by shale of the Kayenta Formation (Late Triassic) that is a barrier to the downward movement of ground water. Springs (S7 and S8, table 7) in Harts Draw on the downdip side of the point, and well (E1) on Harts Point, indicate locally perched water in the lower part of the Navajo Sandstone. Well site 7 was located so as to tap this water-bearing zone.

\section{BUREAU OF LAND MANAGEMENT GRAZING DISTRICT 9}

The area examined (5, fig. 1$)$ is at the north end of Dome Plateau about 6 miles west of Dewey Bridge where Utah Highway 128 crosses the Colorado River. The site proposed by the Bureau of Land Management (8, table 7) is on the north flank of a large domal structure in what is considered a very unfavorable geologic and topographic setting. Therefore, an alternate site (9) was selected about $1 \frac{1}{2}$ miles southwest of site 8 near the axis of a syncline that separates the larger structure from the comparatively small Yellow Cat dome. Site 9 is both topographically and stratigraphically lower than site 8 so that chances are much better that water will be found at comparatively shallow depth in the lower part of the Entrada Sandstone of Late Jurassic age. 


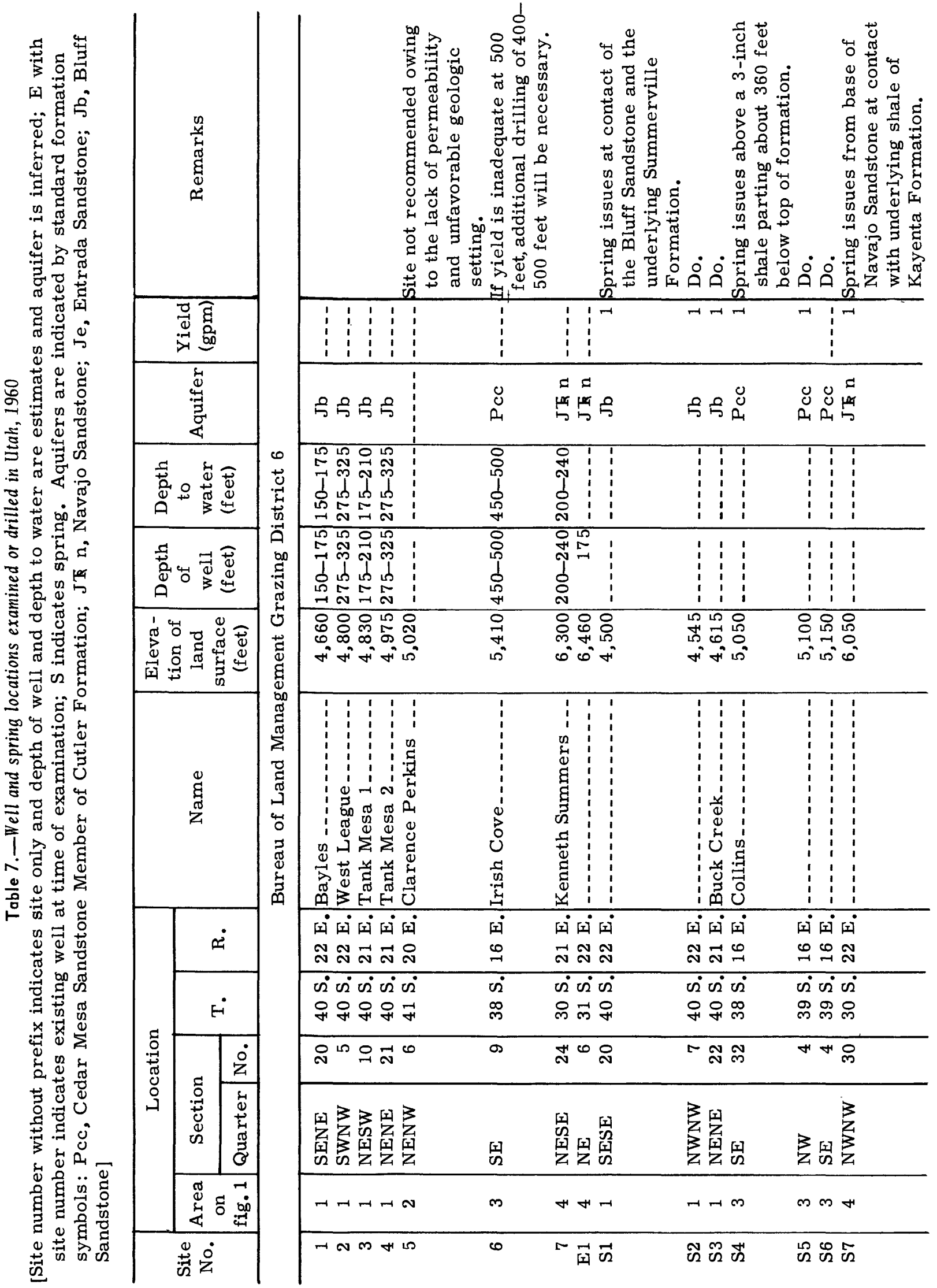




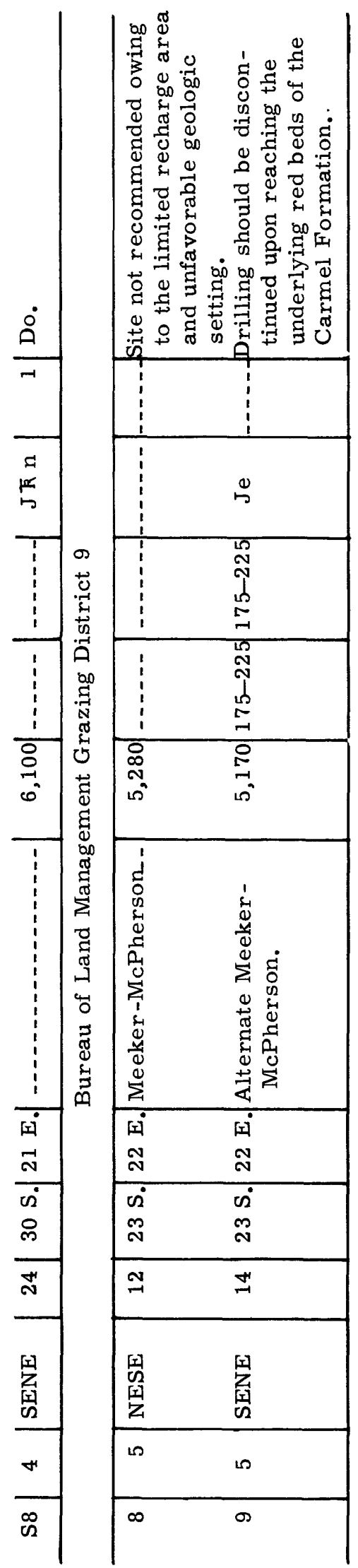

\section{WYOMING}

BUREAU OF LAND MANAGEMENT GRAZING DISTRICT 2

\author{
By M. C. VAN LEWEN
}

The Bureau of Land Management Grazing District 2 comprises parts of Fremont and Natrona Counties. Explorations for water in 1960 were made in 2 areas where 11 well sites were located. Information on eight wells, drilled as a result of recommendations made in 1960 and previous years, is given in table 8. Recommendations for stockwater sources were based on field examinations by the author and R. W. Lichty and on reports by Thompson, Troyer, White, and Pipiringos (1950), Thompson and White (1954), and Tourtelot (1953).

\section{Government Draw area}

Well sites 1, D1, and D2 (table 8) east of Lander are near the drainage divide that separates Government Draw and Beaver Creek (1, fig. 1). This area is underlain by, in descending order, the Wind River (Eocene), Fort Union (Paleocene), and Mesaverde (Late Cretaceous) Formations and the Cody Shale (Late Cretaceous). These formations all strike northwestward and dip northeastward. An angular unconformity exists between the Wind River Formation, which dips $2^{\circ}-3^{\circ}$, and the Fort Union Formation, which dips $12^{\circ}-$ $14^{\circ}$. Angular unconformities of about $2^{\circ} \mathrm{oc}-$ cur between the Fort Union and Mesaverde Formations, and between the Mesaverde Formation and the Cody Shale. All these formations contain permeable beds that, if saturated, will yield water to wells.

Although there are two stock-water wells in the area (E1, E2) that obtain water from the Wind River Formation and from the Cody Shale, the results of drilling at sites D1 and D2 indicate that wells drilled on or near the drainage divide may not obtain an adequate yield. A much better place for developing successful wells is in the Wind River Formation on the broad surface that dips northeast ward to Beaver Creek. Future wells should be drilled at least half a mile, and preferably a mile, northeast of the drainage divide in order to obtain a yield adequate for stock needs. 
Shoshone-Moneta area

Well sites 2, 3, and D3-D8 (table 8) in the northern part of the Wind River basin $(2, \mathrm{fig}$. 1) are underlain by the Wind River Formation, which consists of pockets and lenses of sandstone erratically distributed throughout a thickness of several thousand feet of multicolored shale. Because the lithology of this formation changes radically within short distances, it is generally not possible to predict closely the required drilling depth at a particular location. The results of drilling at six of the above sites (D3-D8) show that, if several wells are to be drilled, the total footage drilled will be reasonably close to the total estimated footage.

Water found at shallow depth in this area is frequently of poorer quality than water found at greater depth. Where this happens, the water obtained at shallow depth is usually cased off and drilling is continued until water of better quality is obtained. Water in the Wind River Formation in this area is commonly under artesian pressure.

\section{BUREAU OF LAND MANAGEMENT GRAZING DISTRICT 4 and 5}

\section{By M. C. VAN LEWEN}

The Bureau of Land Management Grazing Districts 4 and 5 comprise parts of Sweetwater, Lincoln, Uinta, and Sublette Counties. Explorations for water in 1960 were made in the Bridger Basin (3, fig. 1) part of which is in the northern part of District 4 and the remainder of which is in District 5, where 36 well sites were located. Information is given on 7 wells drilledas a result of recommenda tions made in 1960. Recommendations for stock-water sources were based on field examinations by the author and R. W. Lichty and on reports by Bradley $(1926,1959)$, Donovan (1950), and Gordon and others (1960).

The well sites (4-29, D9-D18, table 8) examined are all in the northern half of the Bridger Basin. Ground water occurs under sufficiently similar conditions throughout the area bounded by the Wind River Mountains on the northeast, Steamboat and Essex Mountains on the southeast, the township line between Townships 21 and 22 north on the south, and the Wyoming Range on the west that it may be described as a unit. Bedrock in this area consists of indurated sediments of the Wasatch, Green River, and Bridger Formations all Eocene age that were deposited in and along the margins of the ancient Green River Lake. Bradley (1926) and Donovan (1950) described the depositional environment that resulted in the intertonguing of the Wasatch and Green River Formations. Gordon and others (1960) describe the occurrence and quality of water in the northern Bridger Basin.

Both the uppermost part of the Green River Formation and the overlying Bridger Formation consist of interbedded standstone and shale, and these units contain many more permeable beds than does the main body of the Green River Formation. An analysis of driller's logs of numerous wells drilled in the Little Colorado Desert west of Farson between Sandy Creek and the Green River permits some generalizations of the lithology and water-bearing properties of the formations. Rocks found near the axis of the basin are not readily correlated with exposures along the margin of the basin. Sandstone beds are generally not continuous from one well to another only a few miles away. Yields in excess of $40 \mathrm{gpm}$ have been obtained from the Bridger Formation and from the upper part of the Green River Formation from wells along the major ephemeral streams tapping these horizons. Wells in up land areas away from the stream valleys, however, obtain only small yields from these same stratigraphic horizons. To obtain yields in excess of $20 \mathrm{gpm}$ in these parts of the area, it is generally necessary to drill much deeper, probably to a tongue of the Wasatch Formation.

Along the east and west margins and throughout the northern part of the northern Bridger Basin the Wasatch Formation is recharged by perennial surface streams, so that stock-water wells of adequate yield are usually obtained at a depth of less than 200 feet. A few wells drilled into the Wasatch Formation on the mesa south of Pinedale indicate that small amounts of water may be obtained at elevations considerably above the level of the nearby New Fork and Green Rivers.

Water in the Waśatch, Green River, and Bridger Formations is ordinarily under artesian pressure, and some flowing wells have been developed. All water obtained 
from these formations in this area is suitable for stock use.

\section{BUREAU OF LAND MANAGEMENT GRAZING DISTRICT 6}

\section{By CHARLES E. SLOAN}

Bureau of Land Management Grazing Dis trict 6 comprises parts of Johnson and $\mathrm{Na}$ trona Counties and scattered land utilization tracts in eastern Wyoming and adjacent States. Exploration for water in 1960 was made in three areas where six well sites were chosen, one of which was drilled in 1960. Recommendations for stock-water sources were based on field examinations by the author.

\section{Alkali Creek area}

Two well sites (30 and D19, table 8) were selected in August in the Alkali Creek area (4, fig. 1) near Arminto in the eastern part of the Wind River Basin. Both sites are underlain by the Wind River Formation of Eocene age, which has accumulated to consid erable thickness in a deep, northwestward trending synclinal trough that separates $\mathrm{Ce}$ dar Ridge on the southwest from Arminto anticline on the northeast. The Wind River Formation locally consists of interbedded shale, siltstone, sandstone, and conglomerate of fluvial and lacustrine origin. Both sites were chosen on the basis of three wells (E35E37) that obtain water at a comparatively shallow depth from sandstone lenses in the Wind River Formation within a few miles of the sites. However, the well drilled at the Donlin 1 site (D19) penetrated only "blue clay" to a depth of 300 feet where drilling was dis continued. Thus, the distribution of sandstone lenses in the Wind River Formation appears to be erratic and not locally predictable. Suc cessful completion of wells in this area involves an element of risk, therefore, as water can be found only in permeable sandstone lenses below the local level of saturation.

\section{Bonnidee area}

Well site 31 near the head of Curtis Draw in the southern part of the Powder River Basin (5,fig. 1) was examined in August. The site is about 4 miles west of the Powder River and 250 feet higher. Westward dipping, interbedded sandstone, siltstone, shale, and coal of the Wasatch Formation crop out in the slopes between the site and the river and underlie this general area to a depth of several thousand feet.

Well E38, about half a mile east of the site, indicates that permeable beds occur locally within the Wasatch Formation, and that below the level of the Powder River these beds should be water bearing.

\section{Williams Draw area}

Three well sites (32-34, table 8) were examined in August in the Williams Draw area (6, fig. 1) which is immediately east of the Powder River in the central part of the Pow der River basin. The Wasatch Formation, consisting largely of interbedded sandstone, siltstone, shale, and coal, underlies the area to a depth of several thousand feet. Data from wells E39-E41 indicate that the Powder River reflects the general level of saturation in the Wasatch Formation. Thus, successful well completion depends on penetrating a permeable zone below this level. Owing to the dip of the beds and the confining effect of the shales, the water apparently is under artesian pressure throughout the area.

\section{REFERENCES FOR WYOMING}

Bradley, W. H., 1926, Shore phases of the Green River formation in northern Sweet water County, Wyoming: U.S. Geol. Survey Prof. Paper 140-D.

1959, Revision of stratigraphic nomenclature of Green River formation of Wyoming: Am. Assoc. Petroleum Geologists Bull., v. 43, no. 5, p. 1072-1075.

Donovan, J. H., 1950, Intertonguing of Green River and Wasatch formations in part of Sublette and Lincoln Counties, Wyoming, in Wyoming Geol. Assoc. Guidebook 5th Ann. Field Conf., Southwest Wyoming, 1950: p. 59-67.

Gordon, E. D., King, N. J., Haynes, G. L., Jr., and Cummings, T.R., 1960, Occurrence and quality of water in the northern Bridger $\mathrm{Ba}$ sin and the adjacent overthrust belt: Wyoming Geol. Assoc. Guidebook 15 th Ann. Field Conf., Overthrust belt of Southwestern Wyoming and adjacent areas, 1960: p. 226-247.

Thompson, R. M., Troyer, M. L., White, V.L., and Pipiringos, G. N., 1950, Geology of the Lander area, central Wyoming: U.S. Geol. Survey Oil and Gas Inv. Map OM-112. 


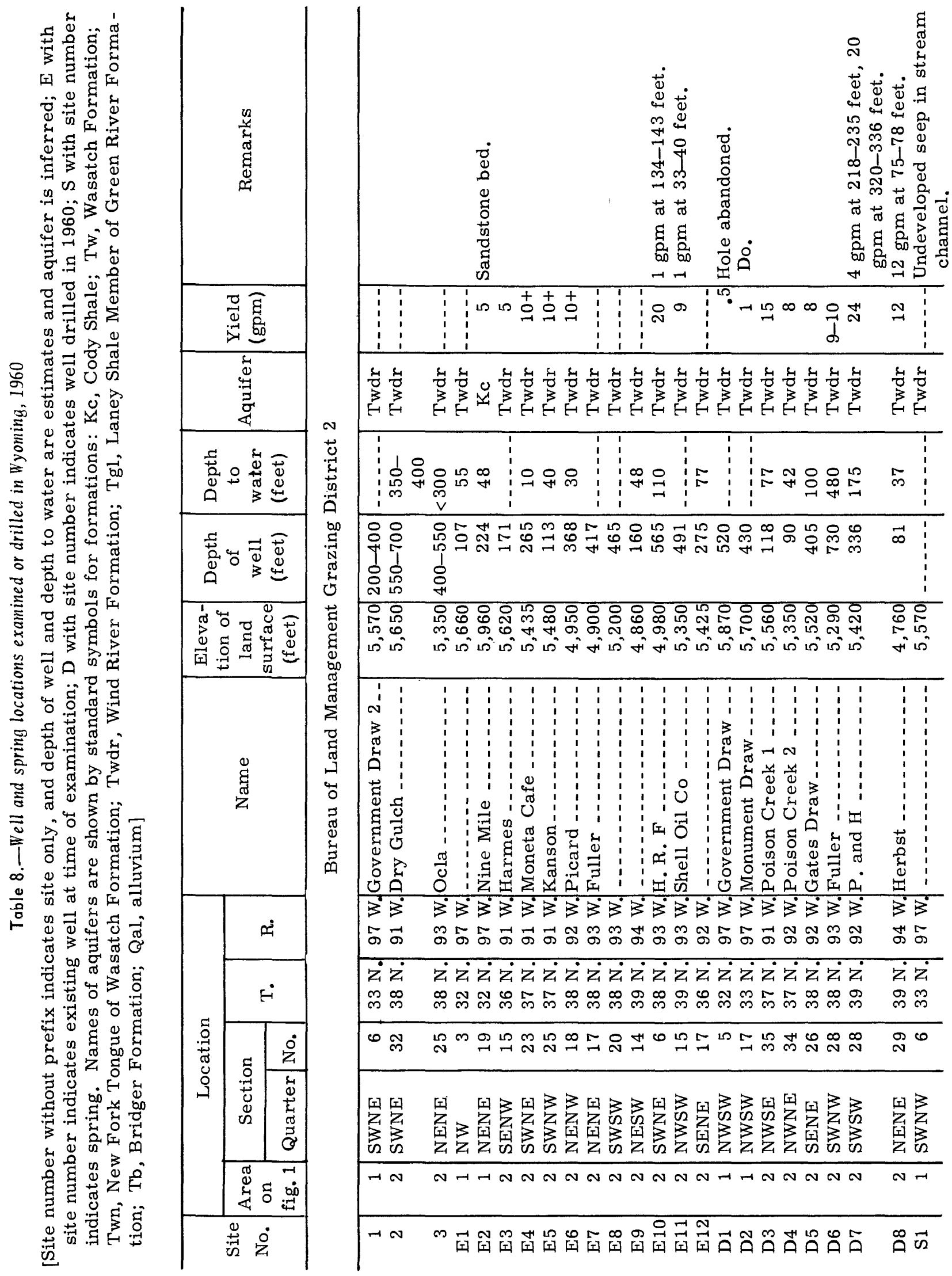




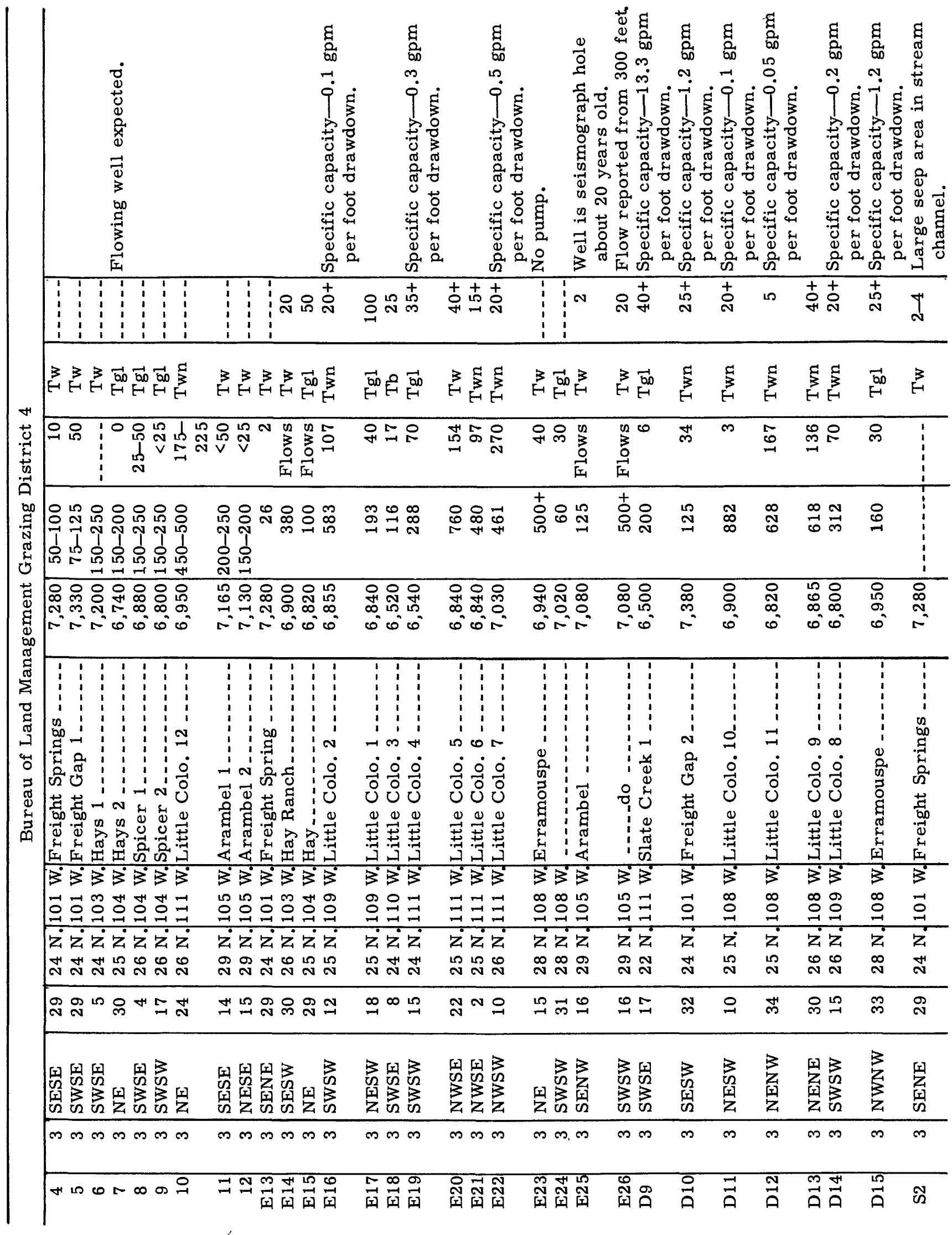




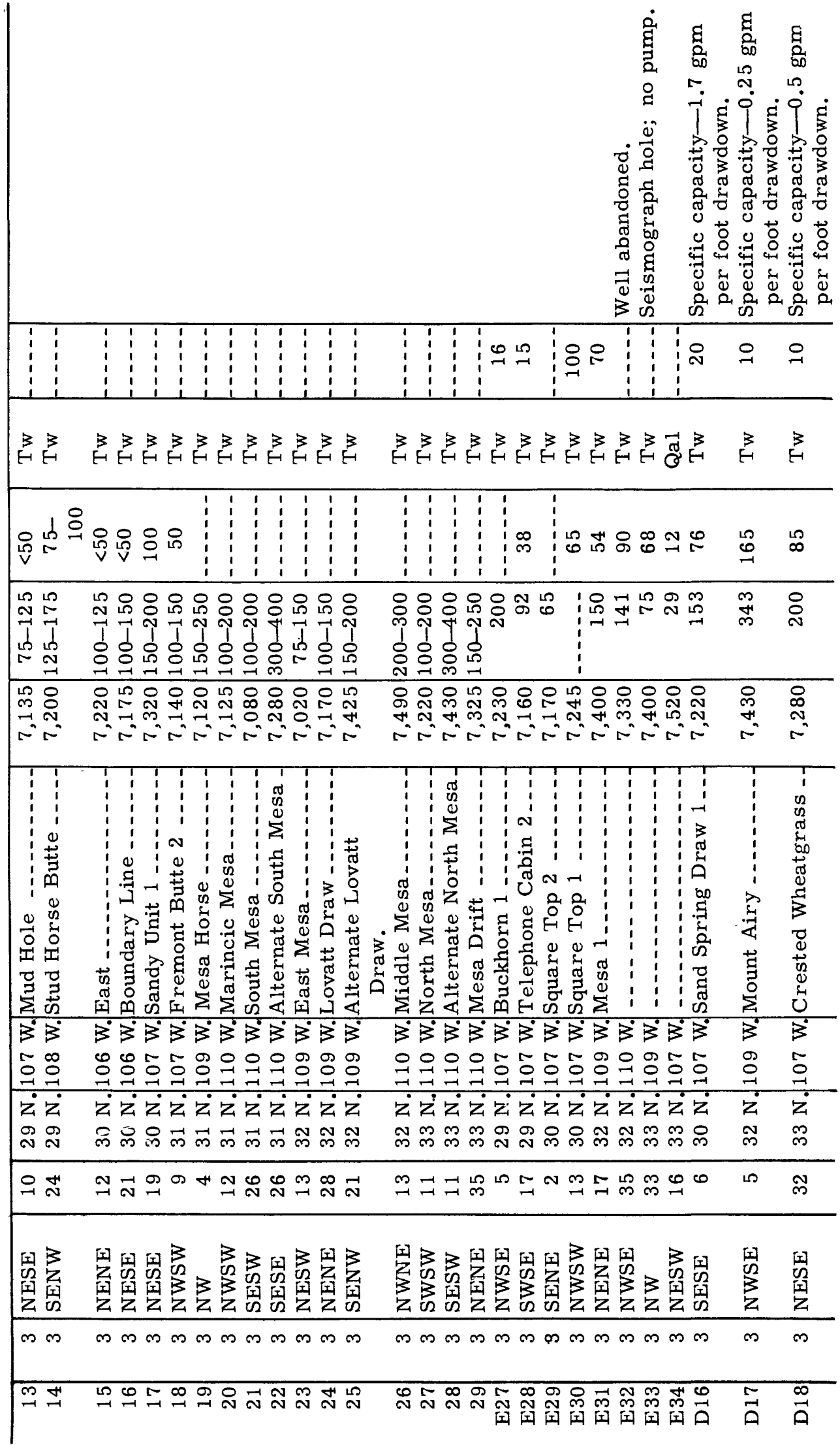




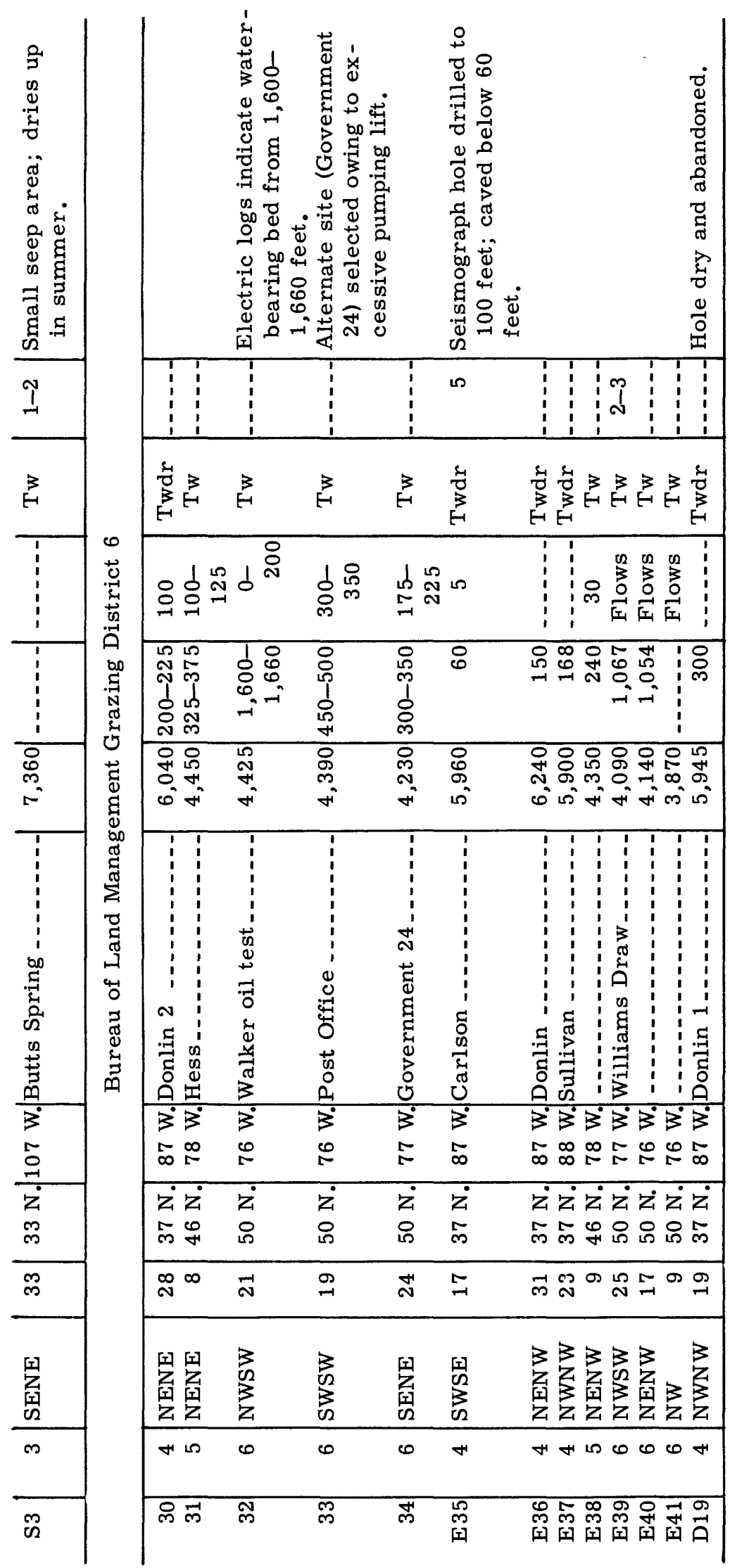


Thompson, R. M., and White, V. L., 1954, Geology of the Riverton area, central Wyoming: U.S. Geol. Survey Oil and Gas Inv. Map $\mathrm{OM}-127$.
Tourtelot, H. A., 1953, Geology of the Badwater area, central Wyoming: U.S. Geol. Survey Oil and Gas Inv. Map OM-124. 